\title{
anu \\ Quantitative Assessment of the Geosites of Chelmos-Vouraikos UNESCO Global Geopark (Greece)
}

\author{
Vasilis Golfinopoulos ${ }^{1}$ [, , Penelope Papadopoulou ${ }^{1}$, Eleni Koumoutsou ${ }^{2,3}$, Nickolas Zouros ${ }^{4}$, \\ Charalampos Fassoulas ${ }^{5}\left(\mathbb{D}\right.$, Avraam Zelilidis ${ }^{1} \mathbb{D}$ and George Iliopoulos $1, * \mathbb{E}$
}

1 Department of Geology, University of Patras, 26504 Patras, Greece; gkolfinopoulosv@upnet.gr (V.G.); penelpapadop@upatras.gr (P.P.); a.zelilidis@upatras.gr (A.Z.)

2 Chelmos Vouraikos UNESCO Global Geopark, 35 Ag. Alexiou Str., 25001 Kalavryta, Greece; koumoutsou@upatras.gr

3 Department of Biology, University of Patras, 26504 Patras, Greece

4 Department of Geography, University of the Aegean, 81100 Mytilene, Greece; nzour@aegean.gr

5 Natural History Museum of Crete, University of Crete, 71202 Heraklion, Greece; fassoulas@nhmc.uoc.gr

* Correspondence: iliopoulosg@upatras.gr

check for

updates

Citation: Golfinopoulos, V.;

Papadopoulou, P.; Koumoutsou, E.;

Zouros, N.; Fassoulas, C.; Zelilidis,

A.; Iliopoulos, G. Quantitative

Assessment of the Geosites of

Chelmos-Vouraikos UNESCO Global

Geopark (Greece). Geosciences 2022,

12, 63. https://doi.org/10.3390/

geosciences 12020063

Academic Editors: Jesús F. Jordá

Pardo and Jesus Martinez-Frias

Received: 29 December 2021

Accepted: 26 January 2022

Published: 29 January 2022

Publisher's Note: MDPI stays neutral with regard to jurisdictional claims in published maps and institutional affiliations.

Copyright: (C) 2022 by the authors. Licensee MDPI, Basel, Switzerland. This article is an open access article distributed under the terms and conditions of the Creative Commons Attribution (CC BY) license (https:// creativecommons.org/licenses/by/ $4.0 /)$.

\begin{abstract}
The assessment of the geosites of Chelmos-Vouraikos UNESCO Global Geopark (UGGp) was carried out based on an established methodology for the evaluation of geoparks' geosites. Such assessments should be used for sustainable development and geoconservation in geoparks. The selected methodology is based on a wider range of criteria concerning the overall value of each geosite, compared to other locations. Each criterion was scored and then three indices, Vedu, Vprot and Vedu were estimated for each geosite. The application of this methodology at Chelmos-Vouraikos UGGp has produced results which not only highlight the value of each geosite, but also provide ways for their utilization. The assessment of the 40 geosites of the geopark, identified geosites with high educational and touristic value (such as Portes-Triklia and the Cave of the Lakes), while geosites with increased protection-need value (the Tectonic Graben of Kalavryta) were also highlighted. Therefore, the assessment results will be used by the geopark to plan the effective management of the geosites based on their strengths and weaknesses, and which thus will promote the geopark and will contribute to the sustainable development of the local communities. The proposed methodology uses all possible criteria for its impartial application and despite a few minor problems that have been identified, it is considered appropriate for the assessment of geosites in Geoparks. The application of such evaluation methodologies is considered crucial for the development, protection and touristic promotion of geoparks.
\end{abstract}

Keywords: geosite assessment; Chelmos-Vouraikos UGGp; geoheritage; geotourism; geoconservation

\section{Introduction}

UNESCO Global Geoparks (UGGps) “are single, unified geographical areas where sites and landscapes of international geological significance are managed with a holistic concept of protection, education, and sustainable development. Their bottom-up approach of combining conservation with sustainable development, while involving local communities is becoming increasingly popular" [1,2]. The concept of geoparks began to evolve in Europe 26 years ago [1,3,4]. The main goal of a geopark is the territorial development of an area with significant geoheritage and natural and cultural wealth as well, in order to promote the sustainable development of local communities through the promotion of geotourism and education [3-5]. Today, there are 169 UNESCO Global Geoparks located in 44 countries around the world [2]. In Greece to date, six areas have been designated as UNESCO Global Geoparks: Lesvos (2000), Psiloritis Natural Park (2001), ChelmosVouraikos (2009), Vikos-Aoos (2010), Sitia (2015) and Grevena-Kozani (2021). According 
to UNESCO [2], UGGps have multidimensional aims which include primarily the protection and conservation of their territorial geoheritage and additionally the cultural and environmentally sustainable development of their territories [6]. Geoscience education offered at all levels is another goal for UGGps promoting awareness about the history of the earth and sustainable development [7]. UNESCO Global Geoparks are basically about humans and about exploring and celebrating the connection between our communities and the Earth [2]. The Earth shapes human identities: it has shaped people's agriculture practices, the building materials and methods that have been used for constructing their accommodation, and even their mythology, folklore as well as folk traditions. In addition, it is the basement for all earth systems and services (natural values, biodiversity, resources, etc.) $[8,9]$. UNESCO Global Geoparks, therefore, engage in a range of activities to celebrate these connections. The Operational Guidelines of the UGGps define 10 focus areas in which the geoparks should develop activities [9] and for which they are evaluated every four years [10]. These areas refer to the natural resources of their territories, and their sustainable use; to geohazards and climate change; to education of local inhabitants and visitors; to natural and cultural heritage; to science and research; to local culture and the celebration of local heritage; to the empowerment of women and equality; to indigenous people and knowledge, if they exist; to the sustainable development through geotourism; and to geoconservation and safeguarding the geological value of their territory.

Over the past three decades, several methodologies for the quantitative and qualitative assessment of Earth's heritage have been developed [11-31] to serve geoconservation and geotourism needs. They aim in minimizing subjectivity in the procedure of organizing the results into an understandable and well recognizable ranking system. Unfortunately, subjectivity cannot be avoided when scoring scientific importance, the need for protection or the potential use of geosites, however, in most cases specific criteria with certain scoring systems are introduced to cope with this problem. When it comes to the preparation of management plans that should be both socially accepted and useful $[18,19]$, the establishment of objective criteria is required [2,5]. The first methods were developed for the assessment of geomorphosites and landscape features in general [11,13,16-18,23-25,27,29], focusing mainly on their aesthetic and scientific values, while others on karst geomorphosites [22,26], or on volcanic geomorphosites [30] as well. Several other methods also induced the assessment of educational [21] and geotouristic values presenting in that way a more complete approach on the overall geosite value $[12,15,20,31]$ Among existing methodologies, quite a few were developed primarily for the need of UGGps to achieve progress on the 10 focus areas $[14,19,28]$. The assessment of the geosites of a geopark not only has a scientific purpose but also aims at the management and conservation of its geological heritage at a certain territorial and legislative context and under the operational framework induced by UNESCO. Geodiversity needs to be considered in a wider view, combining sustainable development with the conservation of geoheritage [19]. Therefore, such assessment becomes a useful tool for site managers, because it highlights and quantifies the priorities needed for the proper management and protection of the geopark. It can also highlight priorities for sustainable tourism development (geotourism and educational tourism) as well as for the conservation of geosites.

The main objectives of this study are, first, the evaluation of the 40 geosites of ChelmosVouraikos UGGp in order to highlight their touristic and educational value as well as the need for their protection, and secondly, the evaluation of the selected methodology, through which its advantages, as well as the respective weaknesses that might need improvement, will be highlighted.

\section{Geopark Outline}

Chelmos-Vouraikos UGGp is located in North Peloponnese (Greece). It occupies an area of $647 \mathrm{~km}^{2}$ with a total population of approximately 27,000 . The area exhibits unique geoheritage, wonderfully combined with rich bioheritage and exceptional cultural and historical elements. To date, 40 geosites have been established in the geopark (Table 1, 
Figure 1). They include unique geological formations (folds, faults, rocks and lithological formations, etc.), karstic geomorphs (caves, poljes, karstic springs), rich geomorphosites (gorges, high peaks, alpine lakes etc) and fossil sites.

Table 1. The geosites of Chelmos-Vouraikos UGGp and their categories. Tectonic (T), Lithological (L), Stratigraphical (S), Karstic (K), Geomorphological (Gm), Hydrological (H), Geotechnical (Gt), Palaeontological (P), Cultural (C).

\begin{tabular}{|c|c|c|}
\hline ID & GEOSITE & CATEGORY \\
\hline 1 & Niamata & $\mathrm{T}, \mathrm{L}, \mathrm{S}$ \\
\hline 2 & Portes-Triklia & $\mathrm{K}, \mathrm{L}, \mathrm{T}$ \\
\hline 3 & Mamousia-Rouskio & $\mathrm{L}, \mathrm{S}$ \\
\hline 4 & Trapeza Marine terrace & $\mathrm{Gm}, \mathrm{T}$ \\
\hline 5 & Kerpini Conglomerates & $\mathrm{L}, \mathrm{Gm}$ \\
\hline 6 & Roghi & $\mathrm{L}, \mathrm{S}$ \\
\hline 7 & Tectonic graben of Kalavryta & $\mathrm{T}, \mathrm{Gm}$ \\
\hline 8 & Agia Lavra & $\mathrm{T}$ \\
\hline 9 & Xidias Lignites & $\mathrm{L}, \mathrm{S}$ \\
\hline 10 & Priolithos & $\mathrm{L}, \mathrm{S}$ \\
\hline 11 & Cave of the Lakes & $\mathrm{K}$ \\
\hline 12 & Mavri Limna & $\mathrm{Gm}, \mathrm{T}$ \\
\hline 13 & Lousoi sinkhole & $\mathrm{K}$ \\
\hline 14 & Aroanios Springs & $\mathrm{K}$ \\
\hline 15 & Mati tou Ladona & $\mathrm{K}$ \\
\hline 16 & Vesini radiolarites & $\mathrm{L}, \mathrm{S}$ \\
\hline 17 & Doxa lake & $\mathrm{H}, \mathrm{Gt}, \mathrm{L}$ \\
\hline 18 & Solos & $\mathrm{L}$ \\
\hline 19 & Tsivlos Lake & $\mathrm{H}, \mathrm{Gm}$ \\
\hline 20 & Water of Styx & $\mathrm{Gm}, \mathrm{S}, \mathrm{K}$ \\
\hline 21 & Xerocambos breccias & Gm, L \\
\hline 22 & Feneos sinkholes & $\mathrm{K}$ \\
\hline 23 & Lousoi polje & $\mathrm{K}$ \\
\hline 24 & Mavrolimni & $\mathrm{Gm}$ \\
\hline 25 & Analipsi & $\mathrm{L}, \mathrm{K}$ \\
\hline 26 & Valvousi & $\mathrm{K}, \mathrm{Gm}$ \\
\hline 27 & Keramidaki & $\mathrm{L}, \mathrm{T}$ \\
\hline 28 & Mega Spilaio & $\mathrm{Gm}, \mathrm{L}, \mathrm{P}$ \\
\hline 29 & Kastria spring & $\mathrm{K}$ \\
\hline 30 & Spanolakkos & $\mathrm{Gm}, \mathrm{L}$ \\
\hline 31 & Palaeochori lignites & $\mathrm{P}, \mathrm{L}$ \\
\hline 32 & Valimi landslide & $\mathrm{Gm}$ \\
\hline 33 & Pausanias Vine & C \\
\hline 34 & Psili Korfi & Gm, T, K \\
\hline 35 & Ntourntourvana & $\mathrm{Gm}, \mathrm{S}, \mathrm{P}, \mathrm{K}$ \\
\hline 36 & Chelonospilia & $\mathrm{Gm}$ \\
\hline 37 & Madero & $\mathrm{Gm}, \mathrm{S}$ \\
\hline 38 & Eroded Conglomerates & $\mathrm{Gm}, \mathrm{L}$ \\
\hline 39 & "Balcony" of Styx & $\mathrm{Gm}, \mathrm{S}$ \\
\hline 40 & Tessera Elata & $\mathrm{Gm}, \mathrm{L}$ \\
\hline
\end{tabular}

At least 485 million years (lower Palaeozoic) of geological history are "unfolded" in the area of Chelmos-Vouraikos UGGp. The alpine basement consists of three geotectonic zones, namely Tripolis Zone, Pindos Zone and the metamorphic Phyllites-Quartzites Suite which is the oldest. Post-alpine formations, whose deposition is related to the Corinth rift, overlap the alpine basement (Figure 1). 


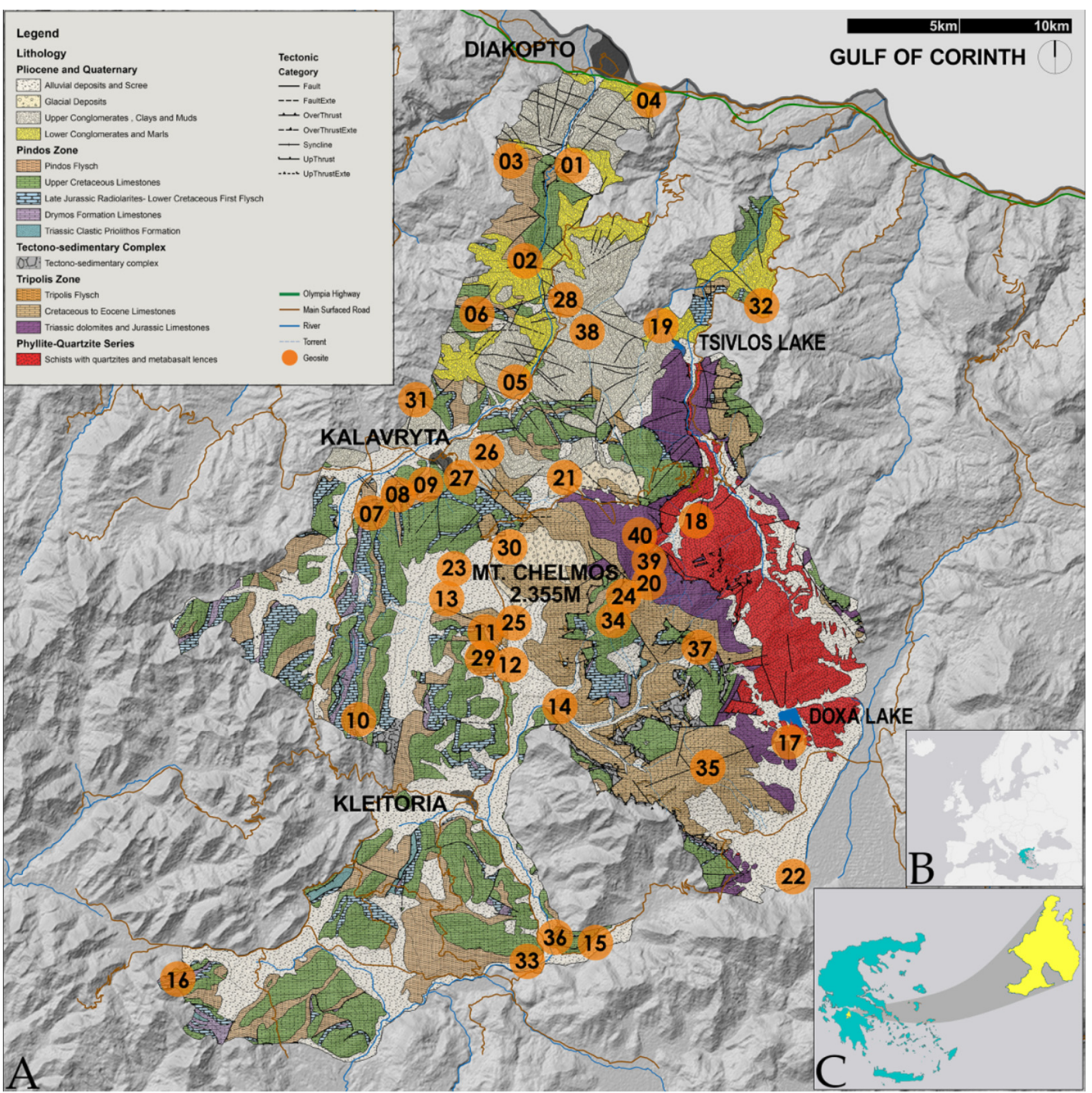

Figure 1. (A) Geological map of Chelmos-Vouraikos UGGp with the locations of the geosites, (B) Map of Europe indicating the position of Greece and (C) Map of Greece with the position of the study area.

Tripolis Zone consists of Mesozoic neritic limestones and dolomites [32], with a maximum visible thickness of approximately $3500 \mathrm{~m}$ [33]. The formations of this unit can be found at the east-southeast part of the geopark, on Chelmos Mt, along Krathis river and at the northern part of Vouraikos gorge. The basement of this zone is the Upper Palaeozoic to Lower Triassic volcano-sedimentary Tyros beds. They consist of a complex of sedimentary and volcanic rocks, which is characterized by a very low grade of metamorphosis. Carbonate sediment deposition in shallow marine environments began during the Early Mesozoic and lasted until the Late Eocene. Flysch formation followed until the end of the Oligocene. The Tripolis Zone underlies sediments of the Pindos zone and post alpine sediments. The whole sequence was overthrusted above the Phyllites-Quartzites Suite.

Pindos Zone develops mainly to the west and south part of the geopark. It consists of a Mesozoic sequence of carbonate and silicate sediments deposited in a deep-sea environment. Their thickness does not exceed $1050 \mathrm{~m}$ [33]. At the base of the sequence, the middle Triassic clastic Priolithos Fm is found. Drymos Fm limestones, with an Upper Triassic-Lower Jurassic age, lie on top of it. The Upper Jurassic to Lower Cretaceous Radiolarites Fm (sensu lato) which overlies the Drymos Fm consists of alternations of pelites, cherts (mainly radiolarites) and limestones with Calpionellids. During the Albian to Cenomanian, the First Flysch Fm was deposited. Upper Cretaceous thin-bedded limestones follow. These limestones during the Late Maastrichtian-Eocene evolved gradually into flysch [34]. 
The rocks of the Phyllites-quartzites Suite appear at the tectonic window of Chelmos Mt, along the Krathis River and in the Feneos plateau (polje) as well. The rocks of this Suite have been formed under high pressure/low temperature metamorphic conditions [35,36]. They consist of phyllites and quartzites that originated from a detrital sequence, whereas in some places mafic rocks are intercalated. Zircon dating methods provided an Early Palaeozoic age for these rocks [37].

Post-alpine sediments (Late Neogene-Quaternary) were deposited across a WNW-ESE direction lying parallel to the Corinth Rift system which is responsible for their formation. The total thickness of these sediments is approximately $2.8 \mathrm{~km}$ [38]. At the north of the study area, five major north-dipping normal faults can be found (from south and older to north and younger): Kalavryta, Kerpini-Tsivlos, Doumena, Pirgaki-Mamoussia and Helike [38]. These faults have confined a series of approximately WNW-ESE north dipping rotated fault blocks associated with the regional N-S extension of the Rift [39]. Accordingly, these fault blocks formed the half-grabens where Pliocene and Quaternary sediments were deposited unconformably on the substrate [40].

According to Ford et al. [41] and Pope et al. [42], at the top of Mount Chelmos, as well as on the surrounding edges, glaciers developed during the Middle-Late Pleistocene. Glaciofluvial brecciated deposits can be found around the mountain's high peaks along with other glacial geomorphological evidence (moraines, cirques, alpine lakes).

The area of the geopark is also valued and protected for its biodiversity and has been classified as a "National Park", managed by the Chelmos-Vouraikos Management Body and taking into consideration (a) the "IUCN Guidelines for Applying Protected Area Management Categories" and (b) the legal framework for conservation management of the Chelmos -Vouraikos National Park pertaining to four Natura 2000 sites (IUCN Management Category II) [43]. It is also rendered as a biodiversity hotspot of the Greek flora and is included in the endemism hotspot region of the mountain ranges of Northern Peloponnesus [44-46]. The natural vegetation of the Chelmos-Vouraikos UNESCO Global Geopark is the result of the interaction of various parameters and mainly of its various orographic configuration, petrological-geological composition, bioclimatic conditions and human activities that have shaped the landscape since historical times. This results in the contemporary, complex land-use fabric which includes semi-natural and natural ecosystems subject to traditional human practices, as well as ecological, historical and culturally important landscapes [10].

The people living in the area are mainly farmers and stockbreeders, who take advantage of the rich resources of their land and produce local products famous for their quality and uniqueness, such as dairy products, honey and legumes. In addition, an important driving force for the local economy is tourism. "Odontotos" rack railway runs across the steep Vouraikos gorge, passing by some of the Geopark's unique geosites, attracting thousands of tourists and giving them the opportunity to admire the incredible geomorphology of the gorge. A popular ski center is hosted at the unique glacial valleys of Chelmos Mt, while the spectacular Cave of the Lakes serves as an exceptional geomorphosite of touristic value. These are classical examples of the way that the geomorphology of the Geopark area shapes the local geotouristic character and provides the means for sustainable development. A large number of tourists is hosted every year at the numerous accommodation facilities that exist in the area.

The area played an important role during the Greek uprisings and for this reason it has a great history. This is witnessed by the numerous monuments of war atrocity which can be found scattered in the area of the geopark (e.g., Holocaust Monument at Kapi hill). The rich history is communicated to the public through the multiple museums (e.g., Holocaust Museum, Folklore-art Museums of Kleitoria and Feneos, etc.). The area has also great archaeological (e.g., archaeological sites of ancient Lousoi and ancient Kleitoria) and religious interest (e.g., historic monasteries of Mega Spilaio and Agia Lavra). One more aspect of the geopark's multidimensional value is its intangible heritage, which is wonderfully expressed through popular art especially music and poetry and mostly 
through the great mythological heritage. The myths and the legends that concern specific parts of the geopark are countless. Characteristic examples are the Feneos sinkholes which are connected to the mythical semi-god Hercules as are also the geosites of Portes-Triklia and Roghi.

The geopark offers a spectrum of promotional tools related to its geoheritage, especially geotrails (seven georoutes) and informative material available at the Information Center of the Management Body. Combined information regarding the geoheritage and its links to biodiversity and culture are presented on the geopark's informative signage.

\section{Materials and Methods}

\subsection{Evaluation Methodologies for Geopark Geosites}

As mentioned above, several methodologies have been developed to assess either certain types of geosites or certain needs (geoconservation, geoeducation, geotourism) [20,23-25,27,47-49]. Synthetic methodologies too, have been developed to assess in certain levels (international, national, etc.) the total values of geosites [17,20,23,24]. More specifically, Brijla [20] reviews the most common and broader applied methodologies for geoheritage assessment, proposing a new one that combines several criteria and tools of previous methods, and which can be applied for geosites and geoheritage sites and at various inventory scales (national, municipal, parks, etc.).

In addition to these, only three main methods so far have been proposed for the quantitative assessment of geoparks' geosites [14,19,28].

Zouros \& Valiakos [14] proposed a quantitative method for the evaluation of the main operating elements of a geopark, which consists of five criteria with different weighting, and each criterion is subdivided into indicators. Each indicator receives a numerical value during the assessment process. The five criteria are: (1) Geology and Landscape, (2) Management Structure, (3) Interpretation and Environmental Education, (4) Geotourism, (5) Sustainable Regional Economic Development. This method represents a general assessment for geoparks, concerning the quality of the geodiversity, operation, visibility, geotourism and local development of a geopark, and thus is not limited to geosite evaluation. Actually, geosite evaluation consists only one out of the five criteria of the assessment. Hence, this assessment can be a great tool for the overall assessment of Geoparks.

The second methodology by Fassoulas et al. [19] is based on previously proposed criteria from existing evaluation methodologies [13,16,17,31]. These criteria were combined in such a way that they can be applied to all categories of geosites and can be used to evaluate all aspects of a geosite's value. This makes the methodology a useful tool for the assessment of geopark geosites, because geoparks contain a variety of different types of geosites. The criteria are the following six: (1) scientific, (2) ecological and protection, (3) cultural, (4) aesthetic, (5) economic and (6) potential for use. Each main group consists of a number of sub-criteria, and a scoring system is implemented to each criterion. Based on these criteria three individual indices are induced, the Vtour on the geotouristic value, the Vedu on the educational value and the Vprot on the conservation need. The method developed by Fassoulas et al. [19] was designed specifically for UGGps (at that time only endorsed but under close collaboration with UNESCO) as a useful tool for the geopark managers. Hence, it assesses sites in respect to the regional context of the geopark (and not the national or international) in order to highlight the local priorities that the managers should focus on for geoconservation, geoeducation or geotourism. Therefore, it uses criteria that take under consideration the multidimensional aims of UGGps and proposes that the assessment should be undertaken by a group of local and invited experts to minimize the subjectivity effect. The method has been widely considered and not only in geoparks (Google scholar citations: 188; Scopus citations: 102).

The third and most recent methodology presented by Aoulad-Sidi-Mhend et al. [28] was developed to select and classify geosites in protected areas, as well as to determine the degree of protection-need of geosites. The applied evaluation is a result of a combination of studies [17,20,31,50]. This assessment is subdivided into four parts: (1) Scientific Value, 
(2) Additional Values, (3) synthesis and result of the Global Value and (4) the Degradation Risk. These parts consist of several criteria, where each criterion is scored with a numerical value. This method focuses mainly on the selection and evaluation of geosites or potential geosites in protected areas, a certainly interesting assessment for evaluating the geological heritage of such an area and contributing to the designation of new geosites.

As one of the two main and practically principal objective of this study is the evaluation of the individual geosites of an UGGp, Chelmos -Vouraikos, we consider that out of the three methods presented above for the evaluation of geoparks' geosites, the most appropriate for the evaluation of geoparks' geosites is the method proposed by Fassoulas et al. [19], which is entirely focused on geoparks. In a second step, we also look for potential weaknesses or misfunctions of the method under the modern needs of geoparks, in order to propose suggestions for its improvement [19].

\subsection{Application of Selected Evaluation Methodology}

Therefore, having in mind the methodology designed by Fassoulas et al. [19], a working protocol was carefully compiled (Table 2), taking into account the related published literature [10,45,51-53], especially that concerning the ecological criteria (flora and fauna). Aiming for a more accurate evaluation of the 40 geosites of Chelmos -Vouraikos UGGp, in situ inspection of each geosite took place by the research group. The geographical coordinates of each geosite were obtained. Moreover, the geosites were photographed and where permitted, rock samples were collected for the creation of the geosites database.

Table 2. Standard protocol for recording geosite characteristics [19].

\begin{tabular}{cc}
\hline NAME & LITHOLOGY \\
\hline REGIONAL UNIT & CATEGORY \\
\hline LONGTITUDE & TECTONIC UNIT \\
\hline LATITUDE & ALTITUDE \\
\hline CODE & \\
\hline & \\
\hline & COMMENTS \\
\hline
\end{tabular}

\begin{tabular}{c}
\hline GEODIVERSITY \\
\hline INTEGRITY \\
\hline ECOLOGICAL IMPACTS \\
\hline PROTECTION STATUS \\
\hline ETHICS \\
\hline HISTORY \& ARCHAEOLOGY \\
\hline RELIGIOUS \& METAPHYSICAL $~ \&$ CULTURE \\
\hline VIEWPOINTS \\
\hline LANDSCAPE DIFFERENCE \\
\hline ACCESIBILITY \\
\hline VISITORS \\
\hline FATESITY OF USE \\
\hline NATILITY
\end{tabular}


Six main groups of criteria are considered in this method [19]: (1) scientific, (2) ecological and protection, (3) cultural, (4) aesthetic, (5) economic and (6) potential for use. Each group is sub-divided into sub-criteria (Table 3) in order to better assess the value of each geosite [19]. The scoring system for every sub-criterion ranges from 1 to 10 and five fixed scores $(1,2.5,5,7.5,10)$ can be applied to the sub-criteria of each group (Table 3$)$. Finally, the value of each criterion was calculated by all members of the research group as the average of the respective sub-criteria scores.

Table 3. List of criteria and description of the scoring system [19].

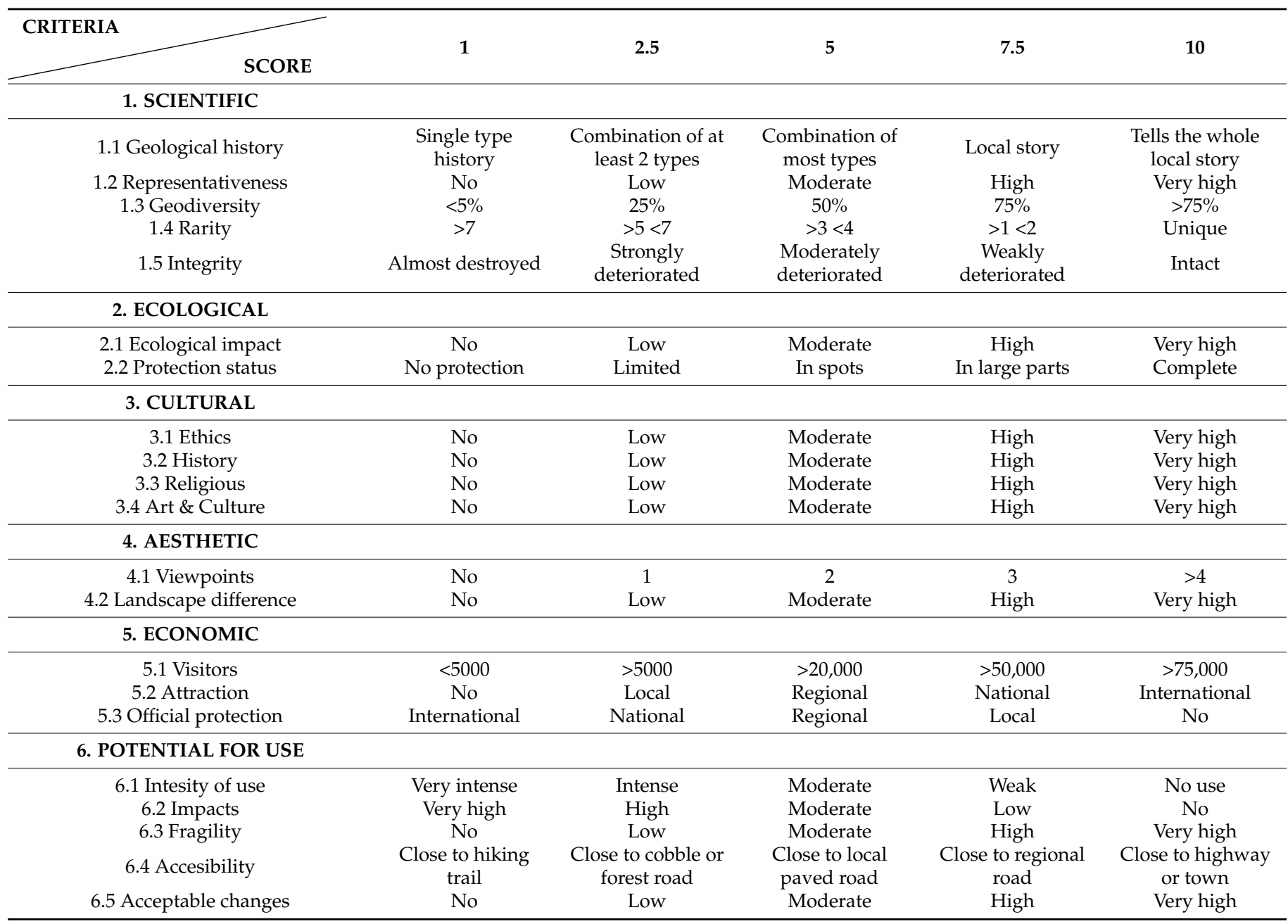

The five scientific sub-criteria assess the scientific value of a geosite (Table 3). These are the Geological history (1.1) that depicts the contribution of a geosite to the interpretation of the overall geological history of a Geopark, the Representativeness (1.2), which addresses the status of the site as an example of the geological heritage of the Geopark, the Geodiversity (1.3), which describes the variety of the identified geological features and processes in a geosite compared to the Geopark's geodiversity, the Rarity (1.4) which concerns the uncommonness of a geosite with respect to similar geosites in the Geopark and the Integrity (1.5) which refers to the existing state of conservation of a geosite, which might be affected by human activities or/and natural processes.

The second group of sub-criteria considers the ecological value of the geosite (Table 3). Ecological impact (2.1) represents the contribution of a geosite to the development of particular ecotopes or to the existence of endemic species within this area, whereas Protection status (2.2) refers to the actual protection and conservation state of the site. 
The four cultural sub-criteria highlight the participation of a geosite to the cultural heritage of the geopark (Table 3), covering all aspects of culture. Ethic importance (3.1) defines the relationship of a geosite with existing ethics or customs, Historical importance (3.2) describes the connection of the site to historical events or archaeological remains, Religious importance (3.3) concerns the religious, metaphysical or mythological value of a geosite and Art and cultural importance (3.4) assesses the presence of the geosite in the arts at a local or regional level.

The fourth group of sub-criteria identifies the aesthetic value of a geosite (Table 3). The two sub-criteria are Viewpoints (4.1) that considers the visibility of the site based on the number of viewpoints from roads or trails around the site located more than $1 \mathrm{~km}$ away from each other and Landscape difference (4.2), which considers the difference in shape, colour or morphology between the landscape background and the geosite.

The economic importance of a geosite is evaluated by three sub-criteria (Table 3). These are Visitors (5.1), which is based on the recorded or estimated number of visitors to the site and which should always be related to the total tourism potential of the Geopark or local region, Attraction (5.2), which considers the importance of the site as a national, regional or local attraction and Official protection (5.3), which describes the legal protection status of a geosite. It has been documented that the high protection status of an area can imply restrictions in many human activities, including economic, sometimes not even permitting the physical human presence in core zones. Therefore, it should be regarded as an economic criterion, and the higher the protection status the lower the scoring should be. In cases where legal protection represents the actual situation, scoring in sub-criterion 5.3 should be regarded as inversely proportional to the scoring of sub-criterion 2.2.

The five potential of use sub-criteria interpret the ability for possible exploitation of a geosite (Table 3). Intensity of use (6.1) indicates the present use of the site by humans, Impacts (6.2) assesses the negative effects of existing human activities on the site, Fragility (6.3) refers to the degree of resistance of a geosite's physical features with respect to potential degradation, Accessibility (6.4) describes the ease of access to the site by road or trails and Acceptable changes (6.5) considers the resistance of a geosite to changes without risking the degradation of its natural features. The last sub-criterion depends on the intensity of use and fragility of the respective geosite.

In addition, based on the values of the six criteria, three indices are calculated for each geosite, the $V_{\text {tour, }}$, referring to the geotouristic value the $V_{\text {edu }}$ for the educational value and the $V_{\text {prot }}$ for the conservation/protection need [19]. The formulae for the calculation of the three indices are using differently weighed coefficients for the specific criteria that are considered for each index, as not all criteria have the same effect on each index. For the geotouristic index the aesthetic, cultural, economic and potential of use criteria are used for its calculation, with the aesthetic criterion considered as more important for this index and thus a 0.4 coefficient is used for it in the formula ( 0.2 for the other three criteria) [19].

Vtour $=(0.4 \times$ Aesthetic $)+(0.2 \times$ Cultural $)+(0.2 \times$ Potential of Use $)+(0.2 \times$ Economic $)$

For the education index, the scientific, aesthetic, cultural, and ecological criteria are used for its calculation, with the scientific criterion considered more important for it and thus a 0.4 coefficient is used for it in the formula ( 0.2 for the other three criteria) [19].

$$
\text { Vedu }=(0.4 \times \text { Scientific })+(0.2 \times \text { Cultural })+(0.2 \times \text { Aesthetic })+(0.2 \times \text { Ecological })
$$

Concerning the calculation of the protection need index, the ecological risk factor $\left(\mathrm{F}_{\mathrm{ecol}}[19]\right)$ needs to be estimated first. This factor calculates the ecological risk of a geosite from the ratio of the Ecological impact score against the Protection status score of the respective geosite. Hence, the calculation of the protection need index is based on the 
scientific criterion and the ecological risk factor, but takes into account as well the Integrity sub-criterion using the formula:

$$
\text { Vprot }=(\text { Scientific }+ \text { Fecol }+(11-\text { Integrity })) / 3
$$

In this way with such a quantitative methodology (scoring scale 1-10) it is much easier to prioritize and identify the geosites that are more important for their geotouristic and educational value and thus take actions to develop them accordingly, and also identify which geosites are vulnerable, facing destruction or deterioration problems, so that protection measures can be undertaken. Therefore, the Fassoulas et al. [19] method has been applied for the evaluation of the 40 geosites of Chelmos-Vouraikos UGGp in order to identify the priorities of Chelmos-Vouraikos UGGp in geoconservation, geoeducation and geotourism development [19].

\section{Results}

The analytic results (criteria scores) of the 40 assessed geosites of Chelmos-Vouraikos UGGp are presented in Table 4 . The average score of the scientific criteria ranges from 2.1 to 9.5, while the score of ecological, aesthetic and economic criteria ranges from 1 to 10 . Furthermore, the cultural criteria values do not exceed 5.9. The criteria for potential use start from 3.9 and reach up to 9.5 .

The geological report and the criteria analysis for ten typical examples of geosites (geosites 2, 7, 11, 14, 19, 20, 24, 28, 35 and 38) are provided in detail in the following sections. These geosites are presented here in detail as they consist some of the most popular and characteristic geosites of the geopark (geosites 2, 7, 11, 14, 19, 28). Some of them also present great need for protection, such as geosites 7 and 14. In addition, very high scores for some of them indicate that they have not been exploited geotouristically so far (geosites $20,24,35)$, while for other geosites, such as geosite 38 , the need for immediate protection is highlighted. 
Table 4. Assessment of the results of the 40 geosites of Chelmos -Vouraikos UGGp.

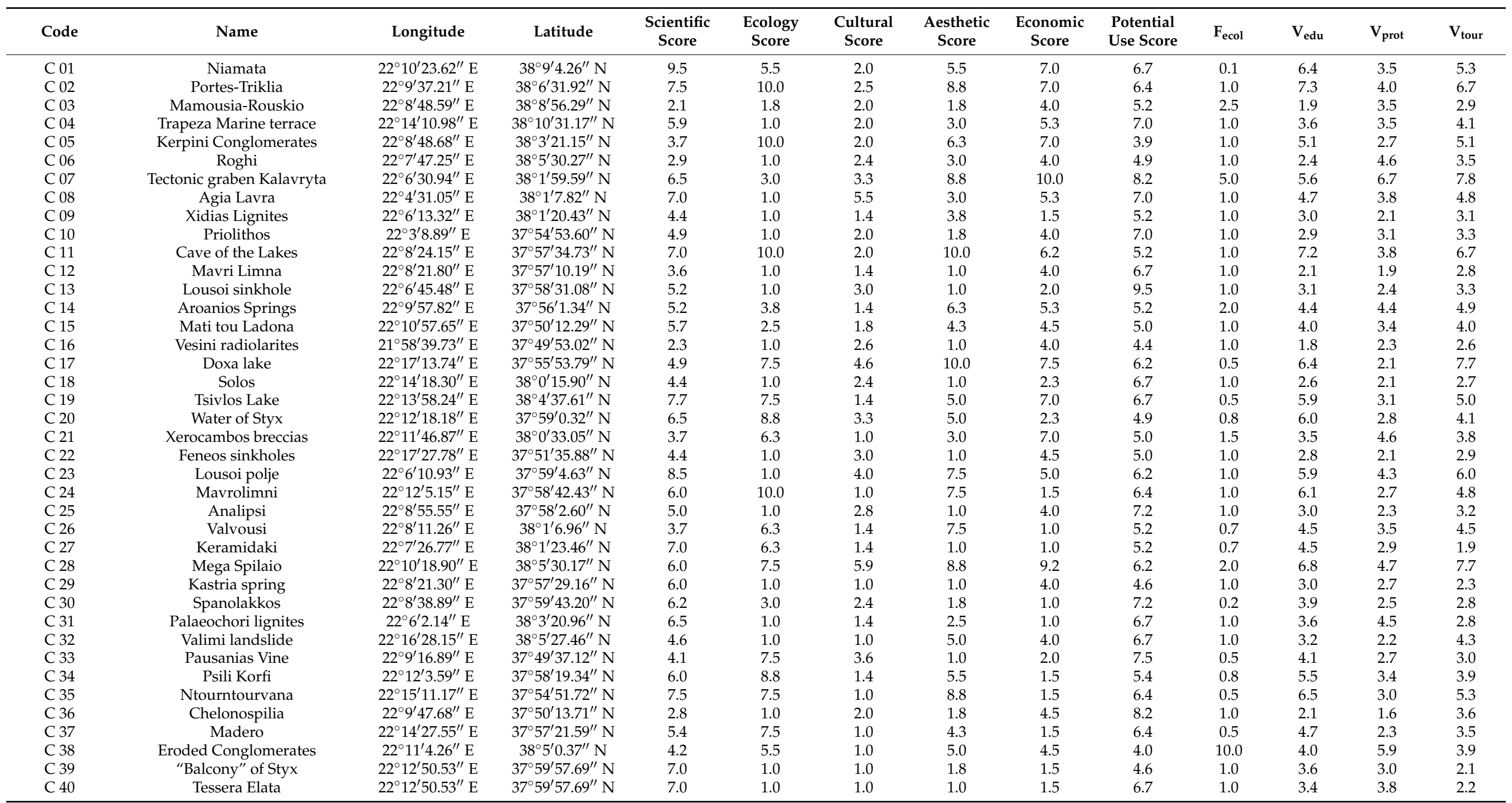




\subsection{Portes-Triklia (Geosite 2)}

Portes-Triklia $\left(38^{\circ} 6^{\prime} 31.92^{\prime \prime} \mathrm{N}, 22^{\circ} 9^{\prime} 37.21^{\prime \prime} \mathrm{E}\right)$ is located in the northern part of the geopark in Vouraikos River Gorge. The area consists of Upper Cretaceous bedded limestones of Pindos zone and fluvial-torrential deposits (Figure 2A). Intense tectonic uplift along normal faults [54] has shaped the gorge in combination with rapid vertical erosion. As a result, an impressive, very narrow and deep gorge was formed during the Lower-Middle Pleistocene $[54,55]$.
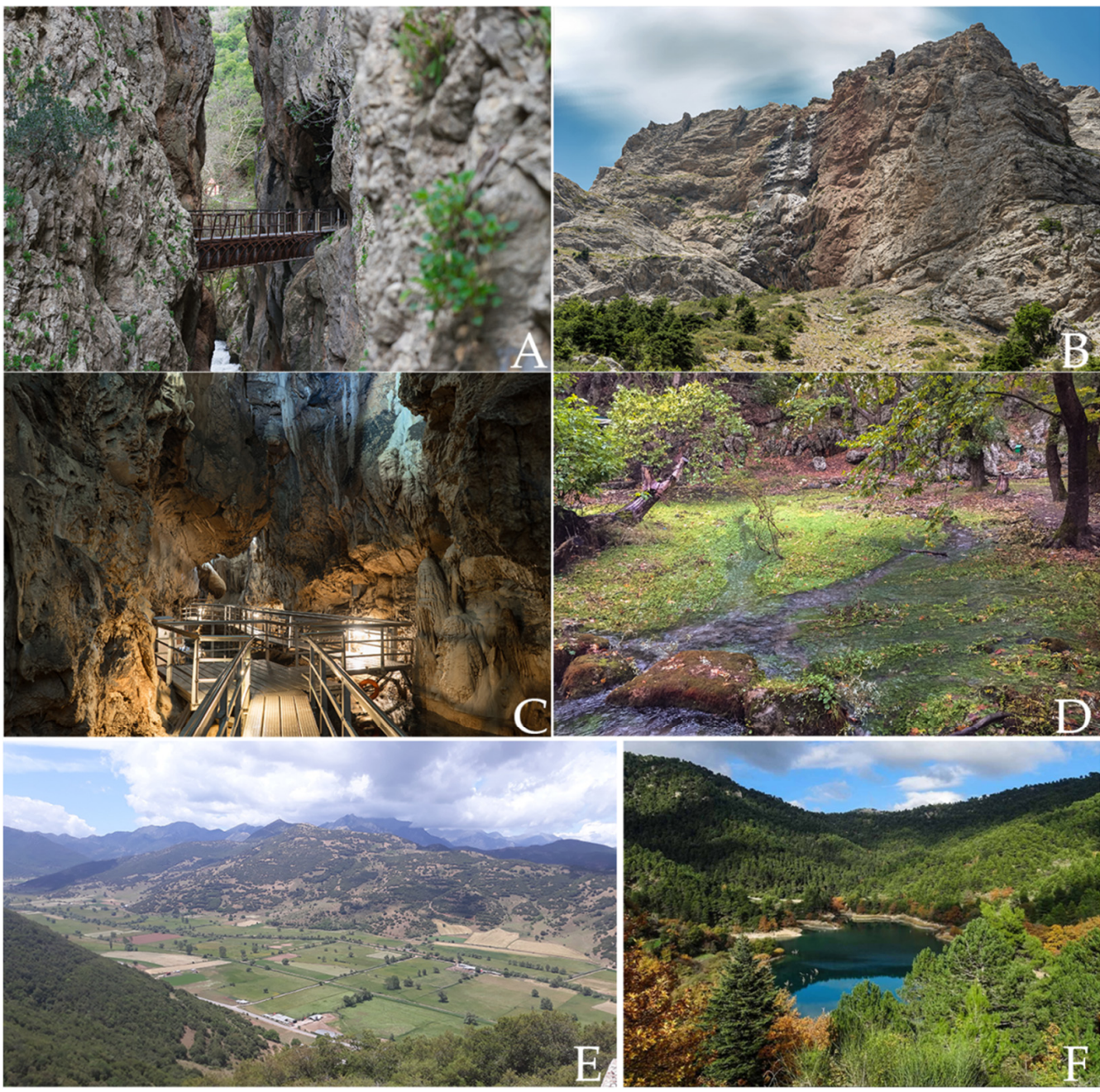

Figure 2. Representative views of the geosites described in the results. (A) Portes-Triklia, geosite 2, (B) The Water of Styx, geosite 20, (C) Cave of the Lakes, geosite 11, (D) Aroanios Springs, geosite 14, (E) Tectonic graben of Kalavryta, geosite 07, (F) Tsivlos Lake, geosite 19.

This geosite exhibits two types of geological history of the studied area: the deposition of Pindos formation and the intense erosional processes of the river (score of sub-criteria 1.1. and 1.2., 2.5 and 10 respectively). The geological features and the processes related to this geosite are the deposition of the limestones of Pindos zone, the deposition of the fluvialtorrential deposits of Vouraikos river, the high rate of uplift of the wider area combined with the intense vertical erosion of the river (score of sub-criterion 1.3. 7.5). This unique combination of features can be found in no other geosite in the geopark (score of subcriterion 1.4. 10). The existing status of conservation from human activity and natural processes is considered slightly damaged due to the construction of the historic "Odontotos" rack railway (score of sub-criterion 1.5. 7.5).

The floristic importance of Vouraikos gorge is very high, due to the presence of rare endemic species. The avifauna of the wider area is also remarkable especially because of 
the high number of species that reproduce there (score of sub-criterion 2.1. 10). The state of actual protection and conservation is very high (score of sub-criterion 2.2. 10) throughout the gorge area.

The European E4 path passes also through this geosite. Its route lies along the Rack railway tracks and is used by thousands of Greeks and foreign hikers every year. The intangible heritage of Vouraikos gorge is invaluable since it is related to Hercules myths. (scores of all sub-criteria of cultural criterion are 2.5 each).

The geosite is not visible from afar mainly due to the dense vegetation but also due to the geomorphology of the area (steep gorge) (score of sub-criterion 4.1.10) and does not differ from the background (score of sub-criterion 4.2. 7.5).

The historic "Odontotos" rack railway is cross passing this geosite attracting thousands of visitors-Greek and foreigners- each year (e.g., 159,789 visitors during 2018 according to the Hellenic Railways Organization) (score of sub-criterion 5.1. 10). Therefore, it is considered an international attraction (score of sub-criterion 5.2. 10). Vouraikos gorge is located in a NATURA A3 zone area (SCI_GR2320003 and SPA_2320013), (score of subcriterion 5.3. 1).

No negative effects from human use have been recorded apparently because it is located in a NATURA A3 protection zone (score of sub-criteria 6.1. and 6.2. 10 each). Its physical parameters are characterized by very high fragility (score of 6.3. 10), so changes are not acceptable without the risk of degradation of the geosite (score of sub-criterion 6.5. 1). The site can be reached either from the homonymous railway stations, or by hiking across the E4 path, departing from Diakopto or Zachlorou (score of sub-criterion 6.4. 1).

\subsection{Tectonic Graben of Kalavryta (Geosite 7)}

The Tectonic Graben of Kalavryta $\left(38^{\circ} 1^{\prime} 59.59^{\prime \prime} \mathrm{N}, 22^{\circ} 6^{\prime} 30.94^{\prime \prime} \mathrm{E}\right)$ is located at the central part of the study area. Kalavryta basin formed during the Early Pliocene due to the N-S extension of the area, being the oldest half-graben of the Corinth Rift (Figure 2E). During the first stages of the basin development, lakes were formed. In these lacustrine environments, layers of clays and marls were deposited, with intercalated lignite layers rich in fossil plants [54]. Alluvial fun sediments fill in the basin upwards [55].

The Kalavryta basin depicts the post alpine geological history of the study area (score of sub-criterion 1.1. 7.5). It is the oldest basin formed due to the continuous rifting process of the Corinth Gulf (score of sub-criterion 1.2. 5). Both the tectonic mechanism of the basin formation and the deposition of the oldest post-alpine formations above the alpine basement are important geological processes that have taken place (score of sub-criterion 1.3. 7.5). Thus, the tectonic graben of Kalavryta is considered unique (score of sub-criterion 1.4. 10). However, it is strongly deteriorated by human activity, since an entire town has been built on it, and has no protection status (score of sub-criterion 1.5. 2.5).

The ornithological value of the area of Kalavryta is characterized high, along with Vouraikos gorge and Chelmos Mt. (score of sub-criteria 2.1. and 2.2. 5 and 1, respectively).

Kalavryta is one of the most historic settlements in Greece, as it is inextricably linked to both the Greek War of Independence (against Ottoman Empire) of 1821 and the German occupation during World War II. Furthermore, the Folklore and Historic Museum and the Museum of the Kalavryta Holocaust (dedicated to the history of the Massacre of Kalavryta in 1943) are located in the city of Kalavryta. Finally, the local train station is the final stop of the historic "Odontotos" rack railway (score of 3.3. 10, while the other cultural sub-criteria were ranked as 1).

The tectonic graben has at least four viewpoints (score of sub-criterion 4.1.-10), and as a low relief surrounded by high peaks it is easily discernable in the landscape (score of sub-criterion 4.2. 7.5).

According to the Kalavryta Hotels Association and the Ski Center of Kalavryta, the number of visitors usually exceeds 75,000 annually (score of sub-criterion 5.1. 10), and thus is considered an international attraction (score of sub-criterion 5.2. 10) but with no official protection (score of 5.3. 10). 
Even though there is very intense human activity in this area (score of sub-criterion 6.1. 10), no negative impact on the geosite has been recorded (score of sub-criterion 6.2. 10), since it has a very high degree of resilience (score of sub-criterion 6.3.-1) in relation to potential degradation (score of sub-criterion 6.4. 10). The place can be reached by car along a well-established road network (score of sub-criterion 6.5. 10).

\subsection{Cave of the Lakes (Geosite 11)}

The Cave of the Lakes $\left(37^{\circ} 57^{\prime} 34.73^{\prime \prime} \mathrm{N}, 22^{\circ} 8^{\prime} 24.15^{\prime \prime} \mathrm{E}\right)$ is located close to Kastria village, at an altitude of $827 \mathrm{~m}$. It extends to the Amolinitsa Mt, along a NW-SE trending fault. The cave develops in Cretaceous limestones of the Tripolis and Pindos zones separated by a fault. The cave is characterised by a relatively small width and a great roof height. The total length is $1950 \mathrm{~m}$, and its elevation is $85 \mathrm{~m}$, covering an area of $20,000 \mathrm{~m}^{2}$. Apart from the rich speleothems, its most impressive feature is the existence of 13 successive underground lakes, which are located at different levels. These lakes were created due to slow water flow and water stagnation, resulting in the formation of calcitic walls (gours or rimstones) which continue to grow until today. Thus, two types of geological history are combined in this geosite (score of sub-criterion 1.1. 2.5 and score of sub-criterion 1.2. 7.5) and a variety of geological processes took place for the formation of its limestones (score of sub-criterion 1.3. 7.5).

Excavations that took place in the first part of the cave found rich archaeological and paleoanthropological remains showing that the cave was inhabited since $5650 \mathrm{BC}$, from the Neolithic to the Late Helladic period. The length of the touristic route in the Cave is $500 \mathrm{~m}$ (Figure 2C).

This geosite is unique in relation to those that have been recognized in the geopark (score of sub-criterion 1.4. 10). The interventions in the cave are considered minimum since all tourist facilities have been built under strict protection measures (score of subcriterion 1.5. 7.5).

In the non-touristic part of the cave, one of the most important across Europe, a winter colony of bats of the species Miniopterus schreibersi [(18,000 individuals), has been recorded (Life Grecabat project) along with nine more bat species (score of sub-criterion 2.1. 10). It is also located within the protected area (Zone B1-SCI_GR2320009) of the Chelmos-Vouraikos National Park (score of sub-criterion 2.2. 10).

According to the myth [56-58], the daughters of the King of Tiryns Proetus, found shelter in a cave on Mount Aroania, north to Nonacris, when they were preoccupied by insanity, for punishment because they insulted the gods [59] (score of sub-criteria 3.1., 3.2., 3.3., 3.4., 1, 1, 5, 1 respectively).

This geosite is underground, it cannot be seen from anywhere except the small natural entrance point that can be seen from the road (score of sub-criterion 4.1. 10). The surface exposure does not differ from the background (score of sub-criterion 4.2. 10).

The visitors to the geosite exceeded 50,000 in 2018 according to official data (score of sub-criterion 5.1. 7.5). Thus, it is considered as a geosite of international level (score of sub-criterion 5.2. 10). It is also located within a protected area (Zone B1) of the ChelmosVouraikos National Park (score of sub-criterion 5.3. 1).

Today, the access to tourists is allowed under strict protection measures (score of sub-criterion 6.1. 2.5). The only negative effect is its oxidation caused by breathing (score of sub-criterion 6.2. 2.5). The degree of resistance of its physical characteristics is thus considered high (score of sub-criteria 6.3., 6.5. 10 and 1, respectively). In addition, it is only $17 \mathrm{~km}$ from the town of Kalavryta which facilitates access to it (score of sub-criterion 6.4. 10).

\subsection{Aroanios Springs (Geosite 14)}

The springs of Aroanios River (a tributary of Ladon River) are located ( $37^{\circ} 56^{\prime} 1.34^{\prime \prime}$ $\mathrm{N}, 22^{\circ} 9^{\prime} 57.82^{\prime \prime}$ E) near the village of Planitero, at an altitude of $600 \mathrm{~m}$. The springs are supplied by waters from Chelmos Mt which are discharged underground through the sinkholes in the Loussoi polje area (geosite 23). At the northeastern part of the polje a 
SE-NW oriented normal fault brings in contact Pindos zone limestones with limestones of Tripolis zone. As a result, the water springs out the Upper Cretaceous limestones all year round from 41 small fault-overflow springs $\left(4 \mathrm{~m}^{2} / \mathrm{s}\right.$ of water) [60] (Figure 2D) (score of subcriterion 1.1. 1, score of sub-criterion 1.3. 2.5). It is considered as a place with a very high degree of geoheritage representativeness (score of sub-criterion 1.2. 10). This geosite along with Geosite 15 (Mati tou Ladona) are the only geosites of this kind in the study area (score of sub-criterion 1.4.-7.5). The existing state of conservation of the geosite is characterized as moderately deteriorated, due to lumbering (score of sub-criterion 1.5. 5).

The springs are located within the most extensive floodplain forest of the geopark, dominated by plane trees (Platanus orientalis), which however has been infected by the "metachromatic ulcer" disease due to anthropogenic impact [61,62] (score of subcriterion 2.1.-5). In fact, the whole forest is not protected (except at the springs) (score of sub-criterion 2.2.-2.5).

Endemic species of fishes inhabit in Aroanios River, (e.g., Salmo magrostigma, Barbus peloponnesius). The area is known for the fish hatchery facilities and traditional watermills. Furthermore, part of the E4 European path crosses this geosite (score of all cultural criteria are 1 except of 3.4. that was scored with 2.5).

The springs are not visible from any other place, due to the dense plane trees (score of sub-criterion 4.1. 7.5). This geosite fully harmonizes with the rest of the beautiful landscape (score of sub-criterion 4.2. 5).

Planitero is a popular destination for tourists all year round but especially during the summer and autumn months (score of sub-criterion 5.1. 7.5). It is considered an attraction of national importance (score of sub-criterion 5.2. 7.5). The geosite is located within the Natura B2 zone "Aroanios Springs" and thus its protection status is considered satisfactory (score of sub-criterion 5.3. 1).

Around the springs there are restaurants (score of sub-criterion 6.1. 7.5). Downstream fish farms and old watermills exist, but they do not have negative impact on the springs (score of sub-criterion 6.2. 7.5). It is considered a geosite of moderate resistance to possible degradation (score of sub-criterion 6.3. 2.5). Thus, changes are not acceptable without damage risk (score of sub-criterion 6.5. 7.5). Its accessibility is considered easy, through a regional road, less than $25 \mathrm{~km}$ from Kalavryta town (score of sub-criterion 6.4.-1).

\subsection{Tsivlos Lake (Geosite 19)}

Tsivlos Lake is located at the northeastern part of Chelmos-Vouraikos UGGp $\left(38^{\circ} 4^{\prime} 37.61^{\prime \prime} \mathrm{N}, 22^{\circ} 13^{\prime} 58.24^{\prime \prime} \mathrm{E}\right)$. The lake was created in 1913 , due to the damming of Krathis river after a large landslide, triggered by the preceding strong rainfalls that destabilized the intensely tectonized rocks of the area, blocked the riverbed [63] (Figure 2F).

Tsivlos lake depicts a unique geological history, with its formation from a landslide (score of sub-criterion 1.1. 1, score of sub-criterion 1.3. 7.5). In the geopark there is no other permanent natural lake (score of sub-criterion 1.2. 10, score of sub-criterion 1.4. 10). The geosite is kept intact, although it is used by visitors as a recreation area (score of sub-criterion 1.5. 10).

Due to the young age of the lake, the riparian vegetation is still not well developed. It is surrounded by densely forested landscapes with mixed Mediterranean coniferous trees (Pinus halepensis, Pinus nigra and Abies cephalonica) (score of sub-criterion 2.1. 5). The state of protection and conservation of the lake is considered very high (score of subcriterion 2.2. 10). Two georoutes have this geosite as a starting point (score of cultural criteria are 1, except of 3.3. 2.5).

This beautiful landscape can be accessed through the local road network (FeneosAkrata) (score of sub-criterion 4.1. 2.5), with a high differentiation from the background (score of sub-criterion 4.2. 7.5). It receives more than 75,000 visitors each year (score of sub-criterion 5.1. 10) and is thus considered an international attraction (score of subcriterion 5.2. 10). The lake belongs to a Natura 2000 B3 protection zone of ChelmosVouraikos National Park (score of sub-criterion 5.3. 1). 
The use by humans around the lake is characterized weak (score of sub-criterion 6.1. 7.5). The hydroelectric power station, which was built 25 years ago, close to the lake to the east, has no negative impact on the environment (score of sub-criterion 6.2. 10). Due to its high fragility (score of sub-criterion 6.3. 7.5), changes are not acceptable either inside the lake or around it (score of sub-criterion 6.5. 1). It can be reached by a detour of the local Feneos-Akrata road (score of sub-criterion 6.4 7.5).

\subsection{Water of Styx (Geosite 20)}

Water of Styx (or Mavroneri) waterfall $\left(37^{\circ} 59^{\prime} 0.32^{\prime \prime} \mathrm{N}, 22^{\circ} 12^{\prime} 18.18^{\prime \prime} \mathrm{E}\right.$ ) is located on Mount Chelmos. It develops on thick bedded to massive Jurassic limestones of Tripolis zone, and flows down a more than $200 \mathrm{~m}$ high cliff, draining the eastern side of Neraidorachi limestone plateau (Figure 2B). It constitutes one of the springs of Krathis River. Near the base of the waterfall there is a small rock shelter a few meters long. The flow of the water on the limestone colors them black, thus the locals named the waterfall after this (Mavroneri = black water). Furthermore, to the northeast, following the path that leads to the geosite, two successive low-angle thrusts can be clearly seen deforming the limestone. Thus, the Water of Styx geosite presents a combination of two types of geological history (score of sub-criterion 1.1. 2.5, score of sub-criterion 1.3. 7.5). The representativeness of the geoheritage of the geopark is high (score of sub-criterion 1.2. 7.5). This geosite is one of the three waterfalls in the study area (score of sub-criterion 1.4. 5). The place is intact by both human activity and natural processes (score of sub-criterion 1.5. 10).

Concerning the ecological features of the geosite, many (at least eight) local endemic species of flora are found (score of sub-criterion 2.1. 7.5). Most of the endemic taxa belong to one of the IUCN risk categories, while G. stygia (named after the Styx myth and the locality) is a priority species for conservation in the EU (Annex II 92/43/EEC). The state of actual protection and conservation is very high (score of sub-criterion 2.2. 10).

This geosite presents significant intangible heritage being a site of great mythological value since it has been connected with several myths related to the ancient Greek gods (Iris, the daughter of Uranus and Tethys and the great oaths of gods and humans above Styx waters, Thetis the mother of Achilles and the famous "Achilles heel" mentioned by Homer and others as well). Due to the morphology of the landscape and the difficulty to access it, Ancient Greeks believed that the water of Styx was a source of immortality [64] (score of cultural criteria are 1, except of 3.3.-10).

The geosite, due to the black colored limestone is prominent from two points on the regional road network (score of sub-criterion 4.1 7.5). A third place is the geosite "Balcony" of Styx (geosite 39). This geosite shows a slight change in color compared to the rest of the background (score of sub-criterion 4.22 .5 ). It is also prominent due to the steep morphology of the cliff.

Visitors do not exceed 5000 per year (score of sub-criterion 5.1. 1) and so it is considered a national attraction (score of sub-criterion 5.2. 5). The geosite is part of the A1 protection zone (SCI_GR2320002) of the National Park (score of sub-criterion 5.3.-1).

The intensity of use is considered weak and is related to the grazing of cattle during the summer months (score of sub-criterion 6.1. 7.5). This use causes a low degree of visual alteration of the landscape (score of sub-criterion 6.2 7.5). The degree of durability is considered very high (score of sub-criterion 6.3. 1), so the changes are acceptable without the risk of landscape degradation (score of sub-criterion 6.5. 1). There are three tracks to approach the site (score of sub-criterion 6.4 7.5).

\subsection{Mavrolimni (Geosite 24)}

Mavrolimni, is a glacial seasonal lake, located on Mount Chelmos at an altitude of $2060 \mathrm{~m}\left(37^{\circ} 58^{\prime} 42.43^{\prime \prime} \mathrm{N}, 22^{\circ} 12^{\prime} 5.15^{\prime \prime} \mathrm{E}\right)$ on bedded limestones of Tripolis zone. To the north of the lake, a moraine ridge was formed due to the movement of glaciers from Psili Korfi or Neraidorachi downstream (Figure 3A). According to Pope et al. [42], the formation of 
the moraine took place during the Middle Pleistocene. The glacial sediments blocked the drainage network resulting in the formation of the alpine lake.

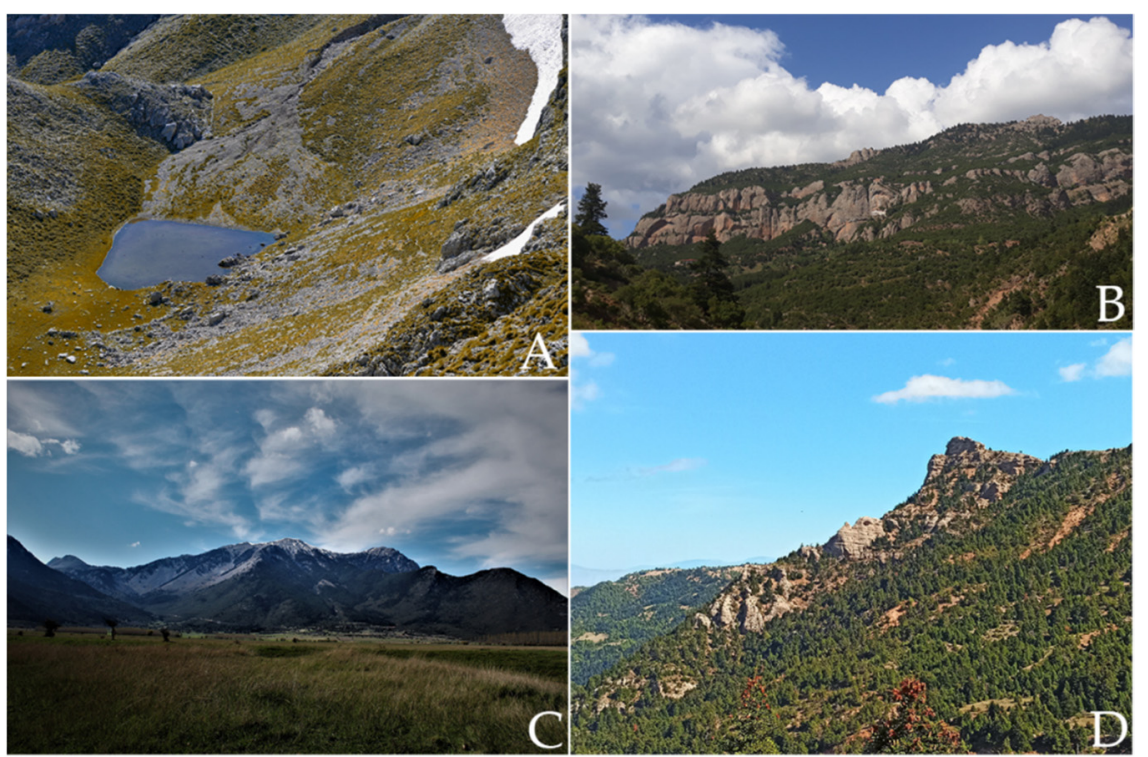

Figure 3. Representative views of the geosites described in the results. (A) Mavrolimni geosite 24, (B) Mega Spilaio, geosite 28, (C) Ntourntouvana, geosite 35, (D) Eroded conglomerates, geosite 38.

Mavrolimni depicts a combination of two types of geological history, (score of subcriterion 1.1.-2.5). In terms of its representativeness, it is considered low in relation to the geoheritage of the entire study area (score of sub-criterion 1.2. 2.5). The geological features and processes in this geosite consist of evidence for the existence of glaciers during the last glacial periods and the preservation of glacial geomorphs such as the seasonal alpine lake (score of sub-criterion 1.3. 5). In the past, there were other smaller lakes of this type on Mount Chelmos which today are dry or destroyed and thus Mavrolimni is recognized as the only geosite of this kind (score of sub-criterion 1.4.-10). As for the current state of preservation from human activity and natural processes, this geosite remains intact (score of sub-criterion 1.5. 10).

Rare endemic species of flora (score of sub-criterion 2.1. 10), such as Aquilegia ottonis subsp. ottonis, Achillea umbellata, Dianthus tymphresteus, Saxifraga sibthorpii have been identified around the lake. It is also characterized by high ornithological value. The actual protection status is considered very high throughout the area (score of sub-criterion 2.2. 10).

No important cultural features are associated with this geosite (all cultural criteria are ranked 1). The lake can be seen from the neighboring high peaks (e.g., Neraidorachi) (score of sub-criterion 4.1. 5). It differs to a very high degree from the background due to its aquatic nature in relation to the surrounding rocky environment (score of sub-criterion 4.2. 10).

Visitors do not exceed 5000 per year, as access to the geosite is only possible after hiking on a demanding track (score of sub-criterion 5.11) and therefore, it is considered as a local attraction (score of sub-criterion 5.2. 2.5). The official protection of this geosite is international since it belongs to a NATURA 2000 A1 zone (High Peaks of Mount ChelmosSCI_GR2320002 and SPA_2320013) of Chelmos-Vouraikos National Park (score of subcriterion 5.3. 1).

There is no use of the site by humans (score of sub-criterion 6.1. 10) and therefore there is no negative impact (score of sub-criterion 6.2. 10). The degree of fragility is considered very high (score of sub-criterion 6.3. 10). No changes are acceptable without the risk of landscape degradation (score of sub-criterion 6.5. 1). The site can be approached only on foot through two different tracks (score of sub-criterion 6.4. 1). 


\subsection{Mega Spilaio (Geosite 28)}

Mega Spilaio geosite is located on the eastern flank of Vouraikos gorge $\left(38^{\circ} 5^{\prime} 25.80^{\prime \prime} \mathrm{N}\right.$, $22^{\circ} 10^{\prime} 28.32^{\prime \prime} \mathrm{E}$ ) and includes highly elevated peaks (maximum altitude more than $1400 \mathrm{~m}$ ). The imposing rocks of Mega Spilaio are mainly composed of conglomerates with steep slopes that in some cases form even vertical cliffs with an altitude difference from the riverbed of more than $800 \mathrm{~m}$ (Figure 3B). The conglomerates were formed in alluvial fan systems in two phases during the Middle Pliocene to Middle Pleistocene. In a sandy clay horizon, fossil bones of large mammals were found. The presence of alluvial fan sediments in such a high altitude is attributed to the tectonic setting of the wider area, the secondary extensional tectonism of the Corinth rift and the resulting great uplift rates [41].

Hence, Mega Spilaio geosite combines different types of geological history (score of sub-criterion 1.1. 5, score of sub-criterion 1.3. 7.5).

Its representativeness for the geoheritage of the geopark is considered moderate (score of sub-criterion 1.2. 5). Kerpini conglomerates geosite (geosite 5) is also a geosite of this category (score of sub-criterion 1.4. 7.5). This outcrop is moderately deteriorated by human activity (construction of the monastery) and natural processes (cavities from the karstification) (score of sub-criterion 1.5.-5).

Mega Spilaio geosite is a place of very high ecological importance (score of subcriterion 2.1. 10), because of the existence of the stenotopic endemic chasmophyte species Silene conglomeratica, located exclusively in cracks of these specific conglomerates, denoting this way the inseparable relationship between biodiversity and geodiversity. Part of the geosite close to the monastery is protected, while the surrounding outcrops are not (score of sub-criterion 2.2. 5).

The historic monastery of Mega Spilaio was built around 362 AD, in a cavity that had been formed by the erosion of the conglomerates, by two monks and is considered the oldest monastery in Greece. During the 1821 Greek War of Independence, the Monastery was a beacon of resistance against the Otomans (score of sub-criterion 3.2. 10). Every August 15, the monastery celebrates the memory of the Assumption of Virgin Mary (score of sub-criterion 3.1. 2.5).

Due to the large thickness of the sequence, the high and steep slopes and the location of the geosite in higher topographies than the surrounding area, it is easily distinguishable from the regional road Pounta-Kalavryta, from the village of Zachlorou, as well as from the surrounding mountain peaks (score of sub-criterion 4.1. 10). This impressive landscape differs in relation to the background if we consider the canyon of Vouraikos River as the local background (score of sub-criterion 4.2. 7.5).

Visitors exceed 75,000 per year (score of sub-criterion 5.1. 10). Thus, it is considered as an international attraction (score of sub-criterion 5.2. 10). Although it is located close to the NATURA 2000 A3 zone of Vouraikos Gorge, the monastery and the respective outcrops are not included within the protected area. However, the monastery has been declared a protected archaeological site (score of sub-criterion 5.3. 7.5).

The use by humans is considered weak (score of sub-criterion 6.1. 7.5), as the monastery currently does not inflict any further destruction to the geosite (score of sub-criterion 6.2. 1). The degree of fragility of its physical characteristics is considered low regarding the cohesiveness of the conglomerates (score of sub-criterion 6.3. 2.5). Thus, changes are acceptable without the risk of degrading its features (score of sub-criterion 6.5. 10). The geosite is easily accessed through the local Pounta-Kalavryta road, just $10 \mathrm{~km}$ before the town of Kalavryta (score of sub-criterion 6.4. 10).

\subsection{Ntourntouvana (Geosite 35)}

Ntourntouvana (or Pentelia) Peak is located $\left(37^{\circ} 54^{\prime} 51.72^{\prime \prime} \mathrm{N}, 22^{\circ} 15^{\prime} 11.17^{\prime \prime} \mathrm{E}\right)$ at the southern margins of Mount Chelmos, standing at an altitude of $2109 \mathrm{~m}$ (Figure 3C). It develops on Cretaceous neritic limestones of Tripolis zone which are in tectonic contact with thin-bedded white dolomites. Rudists and other bivalve shells can be macroscopically observed in the limestone outcrops. In these intensively karstified limestones one of the 
largest and most important potholes of the geopark area the "Hole of Feneos" (maximum depth $130 \mathrm{~m}$ ) is developing. This geosite therefore reflects a large part of the geological history of Mount Chelmos (score of sub-criterion 1.1. 5, score of sub-criterion 1.3. 10).

It is a place with high representativeness for the geoheritage of the geopark (score of sub-criterion 1.2. 7.5). Two more high peaks of Chelmos Mt have been characterized as geosites (Geosite 34: Psili Korfi and Geosite 37: Madero) (score of sub-criterion 1.4. 5). The condition of the geosite, as far as both human activity and natural processes are concerned, is characterized as intact (score of sub-criterion 1.5. 10).

It is a geosite rich in endemic species of mountain-Mediterranean meadows (genus Nar$d u s$ ), chasmophytic vegetation and mountain tea (Sideritis sclandestina subsp. peloponnesica endemic to Peloponnese) (score of sub-criterion 2.1. 5). The existing protection and conservation status are high throughout the Ntourntouvana area (score of sub-criterion 2.2. 10).

This geosite does not display important features of cultural heritage (all cultural criteria are scored 1). Due to its high altitude, this geosite can be observed from many surrounding localities (score of sub-criterion 4.1. 10). Due to the absence of woody plants at Ntourntouvana Peak, the geosite differs from the surrounding area, where forests of black pines and firs grow (score of sub-criterion 4.2. 7.5).

Visitors do not exceed 5000 per year and are limited to mountaineers who hike across its tracks (score of sub-criterion 5.1. 1). Thus, it is considered as a local attraction (score of sub-criterion 5.2. 2.5). Officially, it is included in zone $C$ of the NATURA 2000 area of Chelmos-Vouraikos National Park (score of sub-criterion 5.3. 1).

There is no use of the area by humans (score of both sub-criteria 6.1., 6.2. 10). Due to the rocky substrate, it does not have any degree of fragility (score of sub-criterion 6.3. 1). Therefore, small changes are acceptable without the risk of degrading its physical characteristics (score of sub-criterion 6.5. 10). There are two tracks to approach the site (score of sub-criterion 6.4. 1).

\subsection{Eroded Conglomerates (Geosite 38)}

East of the monastery of Megalo Spilaio, the Eroded Conglomerates geosite is developing $\left(38^{\circ} 5^{\prime} 0.37^{\prime \prime} \mathrm{N}, 22^{\circ} 11^{\prime} 4.26^{\prime \prime} \mathrm{E}\right)$. It is composed of different Lower-Middle Pleistocene cohesive conglomerates. They were deposited as fan deposits of larger or smaller rivers [54]. Due to the high-altitude, strong winds dominate the microclimate. They erode the cohesive conglomerates forming surface geomorphs, resulting in an impressive landscape (Figure 3D). The Eroded conglomerates geosite depicts a combination of two types of geological history (score of sub-criterion 1.1. 2.5).

It is not considered representative for the geoheritage of the geopark (score of subcriterion 1.2. 1), while geodiversity is characterized as low (score of sub-criterion 1.3. 2.5). Along with the Kerpini Conglomerates geosite, they are considered as two geosites depicting similar processes (score of sub-criterion 1.4. 7.5). The continuous erosion of wind and water deforms slowly the geosite. However, this process is considered slow and natural. Moreover, this is what characterizes this geosite. For this reason, it is characterized as weakly deteriorated (score of sub-criterion 1.5. 7.5).

The ornithological value of the site is considered important (score of sub-criterion 2.1. 10), however, the area is not protected (score of sub-criterion 2.2. 1).

No cultural heritage features are related to this specific geosite (all cultural criteria are scored 1). This geosite can be seen from two points on the local road network (score of sub-criterion 4.1. 5). It shows a moderate difference from the rest of the landscape due to the presence of fir trees (score of sub-criterion 4.2. 5). The visitors are limited to those who hike across the Kalavryta to Mega Spilaio georoute (total length $36.5 \mathrm{~km}$ ). They do not exceed 5000 per year (score of sub-criterion 5.1. 1), and thus it is considered a local attraction (score of sub-criterion 5.2. 2.5). There is no official protection status for this geosite (score of sub-criterion 5.3. 10).

Its use is characterized as moderate due to grazing as well as to the presence of small farming facilities for animal watering (score of sub-criterion 6.1. 5), which alter the 
aesthetics of the landscape (score of sub-criterion 6.2. 5). In addition, this is a geosite with low fragility (score of sub-criterion 6.3. 2.5) and therefore changes are acceptable (to a moderate degree) without the risk of landscape degradation (score of sub-criterion 6.5. 5). The geosite can be accessed either using the aforementioned track, or from the Waters of Styx-Mega Spilaio georoute. Furthermore, visitors can approach the place by car using a forest road $(3.6 \mathrm{~km})$. However, this road is not free to public, and passage is allowed only after a special permit (score of sub-criterion 6.4. 2.5).

\subsection{Synthesis of Results}

As far as the scientific criteria are concerned, the scores range from 2.1 to 9.5. More specifically, the highest values are presented by Geosite 1 (Niamata) (9.5) and Geosite 23 (Lousoi polje) (8.5). This high score is attributed to the depiction of a large part of the geological history of the study area.

The ecological criteria cover the full scores' range (1 to 10). Geosites 2 (Portes-Triklia), 5 (Kerpini conglomerates), 11 (the Cave of the Lakes) and 24 (Mavrolimni) present the highest score (10). Geosites 20 and 34 (Water of Styx and Psili Korfi, respectively) are classified slightly lower (8.8). These geosites present very high ecological importance in combination to their high protection status.

The rating of the cultural criteria ranges from low to medium (1 to 5.9). More specifically, Geosite 11 (Mega Spilaio) presents the highest score (5.9) because of its very high religious interest. Geosite 8 (Agia Lavra) follows (5.5) with moderate historical and religious interest. Geosite 17 (Doxa lake) with 4.6 is also at the same score level mainly because of its religious and historical significance. Finally, Geosite 33 (Pausanias Vine), with 3.6, is considered a geosite of mainly historical interest.

The aesthetic criteria score shows a wide range as well (1 to 10). Geosites 11 and 17, Cave of the Lakes and Doxa Lake, respectively, present the highest value, (10). Geosite 11 (Cave of the Lakes), although it cannot be observed from other locations being underground, is one of the most popular geosites of the geopark with amazing speleothems. Geosite 17 (Lake Doxa) is highly visible from many viewpoints of the surrounding area and has a very high landscape diversity. Geosites 2 (Portes-Triklia), 7 (Tectonic Graben of Kalavryta), 28 (Mega Spilaio) and 35 (Ntourntouvana) present also a very high score (8.8).

The score of the economic criteria varies from 1 to 10. Geosite 7 (Tectonic Graben of Kalavryta) has been scored with 10. Geosite 28 (Mega Spilaio) also presents a very high score (9.2). The exceptionally high scores of the aforementioned geosites are mainly attributed to their very high visibility.

The score of the criteria for potential use ranges from 3.9 to 9.5. Geosite 13 (Lousoi sinkholes) bear the highest score for this criterion (9.5), followed by geosites 7 and 36 (Tectonic graben of Kalavryta and Chelonospilia).

As suitable geosites for educational activities are considered those geosites with values of $\mathrm{V}_{\text {edu }}$ exceeding 6 (Figure 4). These are (in descending order) the geosites Portes-Triklia (C 02, $\mathrm{V}_{\text {edu }}=7.3$ ), the Cave of the Lakes (C 11, $\left.\mathrm{V}_{\text {edu }}=7.2\right)$, Mega Spilaio $\left(C 28, V_{\text {edu }}=6.8\right)$, Ntountouvana $\left(C\right.$ 35, $\left.V_{\text {edu }}=6.5\right)$, Niamata $\left(C\right.$ 01, $\left.V_{\text {edu }}=6.4\right)$, Doxa lake $\left(C\right.$ 17, $\left.V_{\text {edu }}=6.4\right)$ and Mavrolimni $\left(C 24, V_{\text {edu }}=6.1\right)$. Geosites with moderate educational value $\left(4 \geq \mathrm{V}_{\text {edu }} \leq 6\right)$ include the geosites (in descending order) Water of Styx (C 20, $\left.\mathrm{V}_{\text {edu }}=6\right)$, Lousoi polje $\left(\mathrm{C} 23, \mathrm{~V}_{\text {edu }}=5.9\right)$, Tsivlos lake $\left(\mathrm{C} 19, \mathrm{~V}_{\text {edu }}=5.9\right)$, the Tectonic Graben of Kalavryta $\left(C\right.$ 07, $\left.V_{\text {edu }}=5.6\right)$, Psili Korfi $\left(C 34, V_{\text {edu }}=5.5\right)$, Kerpini conglomerates (C 05, $\left.\mathrm{V}_{\text {edu }}=5.1\right)$, Water of Styx $\left(C 20, V_{\text {edu }}=5.1\right)$, Agia Lavra $\left(C\right.$ 08, $\left.V_{\text {edu }}=4.7\right)$, Madero $(C 37$, $\left.\mathrm{V}_{\text {edu }}=4.7\right)$, Valvousi (C 26, $\left.\mathrm{V}_{\text {edu }}=4.5\right)$, Keramidaki (C 27, $\left.\mathrm{V}_{\text {edu }}=4.5\right)$, Aroanios springs $\left(C 14, V_{\text {edu }}=4.4\right)$, Pausanias Vine $\left(C\right.$ 33, $\left.V_{\text {edu }}=4.1\right)$, Mati tou Ladona $\left(C 15, V_{\text {edu }}=4\right)$ and the Eroded conglomerates $\left(C 38, V_{\text {edu }}=4\right)$. Geosites Ntourntouvana, Psili korfi, Water of Styx and Madero remain unused for educational purposes mainly as access to these sites is difficult. 


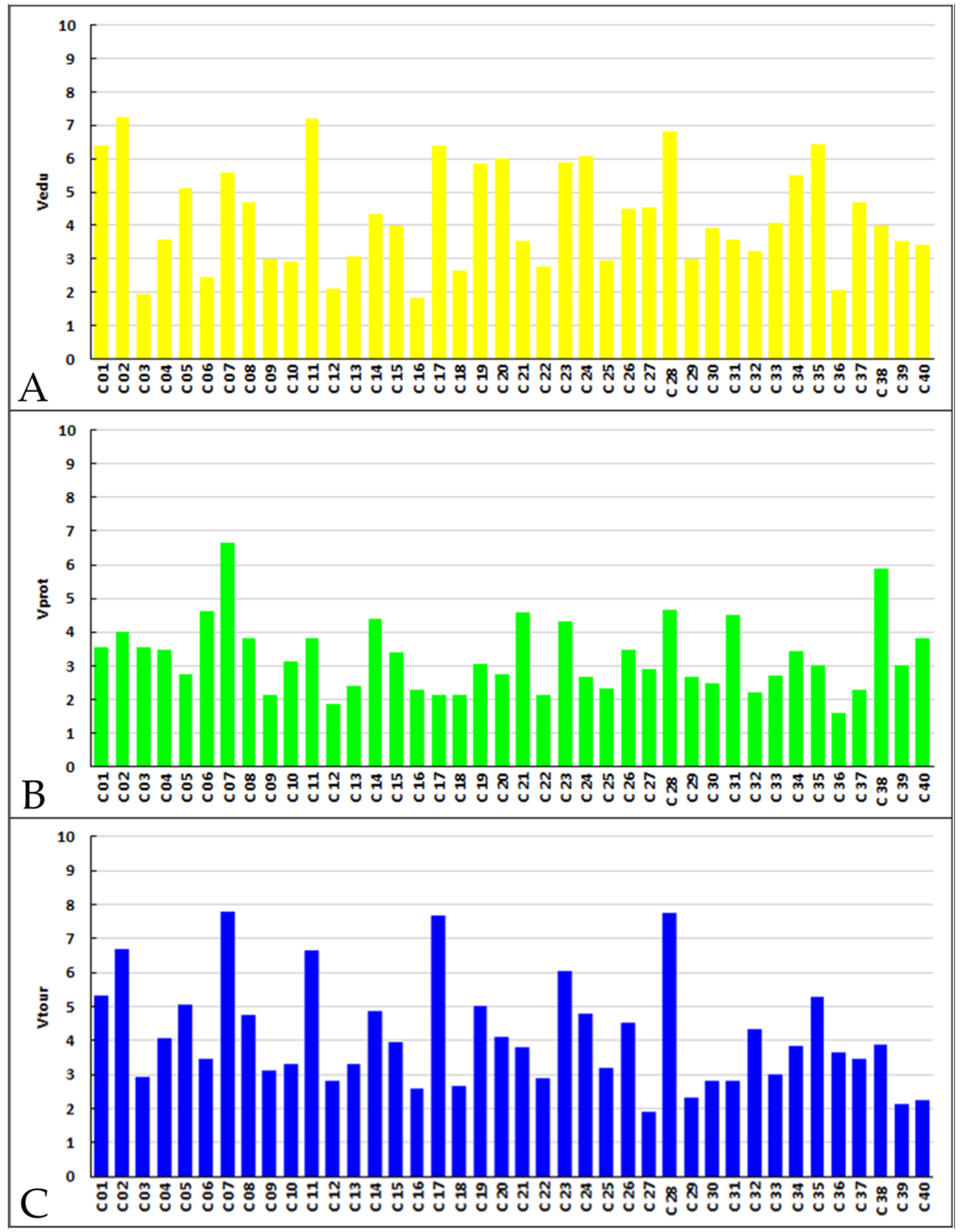

Figure 4. Diagrammatic representation of the results of the calculation of the three indices resulting from the assessment of Chelmos-Vouraikos UGGp geosites, (A) $V_{\text {edu }},\left(\right.$ B) $V_{\text {prot, }}(\mathbf{C}) V_{\text {tour }}$.

Regarding the geotouristic value of the geosites index $V_{\text {tour }}$ is considered (Figure 4). The highest values are presented by Tectonic Graben of Kalavryta $\left(C 07, V_{\text {tour }}=7.8\right)$, Mega Spilaio (C 28, $\left.\mathrm{V}_{\text {tour }}=7.7\right)$, Doxa lake $\left(\mathrm{C} 17, \mathrm{~V}_{\text {tour }}=7.7\right)$, the Cave of the Lakes (C 11, $\left.\mathrm{V}_{\text {tour }}=6.7\right)$, Portes-Triklia $\left(C\right.$ 22, $\left.\mathrm{V}_{\text {tour }}=6.7\right)$ and Lousoi polje $\left(C 23, \mathrm{~V}_{\text {tour }}=6\right)$. Lower values $\left(4 \geq \mathrm{V}_{\text {tour }}<6\right)$ are presented by the following geosites (in descending order): Niamata (C 01, $\left.\mathrm{V}_{\text {tour }}=5.3\right)$, Kerpini conglomerates $\left(C 05, V_{\text {tour }}=5.1\right)$, Tsivlos lake $\left(C 19, V_{\text {tour }}=5\right)$, Aroanios springs $\left(C 14, V_{\text {tour }}=4.9\right)$, Agia Lavra $\left(C\right.$ 08, $\left.V_{\text {tour }}=4.8\right)$, Mavrolimni $\left(C 24, V_{\text {tour }}=4.8\right)$, Valvousi $\left(C 26, V_{\text {tour }}=4.5\right)$, Valimi landslides $\left(C\right.$ 32, $\left.V_{\text {tour }}=4.3\right)$, Ntourntouvana (C 35, 
$\left.\mathrm{V}_{\text {tour }}=5.3\right)$, Waters of Styx $\left(C 20, V_{\text {tour }}=4.1\right)$, Trapeza Marine terrace $\left(C\right.$ 04, $\left.V_{\text {tour }}=4.1\right)$ and Mati Tou Ladona (C 15, $\left.\mathrm{V}_{\text {tour }}=4\right)$. Ntourntouvana and Water of Styx geosites are not yet touristically exploited due to difficult access.

Geosites that according to the $\mathrm{V}_{\text {prot }}$ index, show the greatest need for protection are the Tectonic Graben of Kalavryta $\left(C\right.$ 07, $\left.V_{\text {prot }}=6.7\right)$ and the Eroded conglomerates $(C 38$, $\left.V_{\text {prot }}=5.9\right)$, (Figure 4). The need for protection of the Tectonic Graben of Kalavryta Geosite concerns the very high human activity (farming, industry, etc.) which is spotted in the wider area. The Eroded conglomerates geosite needs protection from overgrazing that has caused alteration in the landscape.

As far as the ecological risk factor $\left(\mathrm{F}_{\mathrm{ecol}}\right)$ is concerned, the highest value is held by the Eroded conglomerates geosite $\left(\mathrm{C} 38, \mathrm{~F}_{\mathrm{ecol}}=10\right)$. The $\mathrm{F}_{\mathrm{ecol}}$ is also particularly high in the Tectonic Graben of Kalavryta $\left(C 07, \mathrm{~F}_{\mathrm{ecol}}=5\right)$. Therefore, there is an urgent need for official protection in these geosites.

\section{Discussion}

Over the last decades, geoconservation [65] approaches have become very popular, contributing significantly as an important component of nature conservation practices [66]. Deterioration of the environment driven by the constantly increasing human pressure to our planet has made clear the need to record, protect and promote not only biodiversity but geodiversity as well [67]. Preserving geological heritage has thus become a key factor for future legislation and policies that would allow the more effective management of the natural environment through the protection of geosites [68]. To achieve these goals, geosite conservation practices need to be implemented to limit anthropogenic and natural deterioration or destruction [69]. Nevertheless, to plan or take specific geoconservation measures for geosites and particularly in places where geoconservation can be enhanced such as geoparks, geosite assessments need to be implemented first to identify their value, possible threats and the need for protection $[69,70]$.

Except for geoconservation, geoparks in their effort to promote sustainable development and economic benefits for local communities through geotourism and education, have also as main goals the connection of nature with people and the connection of geodiversity with biodiversity, cultural heritage and local communities [68,71,72]. Through geotouristic and educational activities organised by the geoparks, geoscientific knowledge and geoconservation concepts are transferred to the public [72].

To succeed in all these, a more holistic approach for the sustainable management of geoparks is required, that will combine sustainable development activities with effective geoconservation which will promote geoheritage values [71]. The first step, however, before geopark management approaches are developed, is the assessment of a geopark's geosites where scientific, cultural, ecological and economic criteria are considered. Thus, employing a method for the assessment of geosites such as the Fassoulas et al. [19] method, which was particularly developed to meet the needs of UGGps, is considered as a good starting point for the management planning of the Chelmos-Vouraikos UGGp.

The evaluation method of Fassoulas et al. [19] has provided very detailed information regarding the value of each geosite and its needs. It takes into account all the existing parameters so that a geosite can be scored impartially and completely. The large range of the grading system (1 to 10) provides the opportunity for a more detailed assessment of the criteria.

Nevertheless, during the evaluation of the results after the application of this methodology, some minor discrepancies became apparent. Concerning the aesthetic criteria (criteria 4.1. and 4.2.), in the case of caves and generally underground geosites, some improvements are certainly needed. We have to stress here that during the development and testing of the methodology [19], no caves were used under the assessment process and thus no certain specifications are provided for their scoring. In our case, particular caves present low visibility and for this reason they bear a low score on this criterion. However, these geosites are often very popular and aesthetically enhanced and thus this criterion 
scoring gives a misleading impression. A characteristic example is the Cave of the Lakes geosite. Hence, application of another evaluation methodology which was created for karst systems, by Li et al. [22] was put under consideration. However, this methodology was difficult to be carried out in this case, due to the fact that a lot of different geosites, such as karstic geomorphs, gorges and rivers, should be taken into account as well. Therefore, the above method could have been applied only for these geosites, since most of the geosites of Chelmos-Vouraikos UGGp do not fall into the above category. Thus, this method is not appropriate for the evaluation of all geosites of the geopark but just for a number of them. To overpass the problem with Fassoulas et al. [19] methodology, if criteria 4.1 and 4.2 are treated for caves under their strict meaning (number of view points, or landscape difference), we should consider the underground aesthetic image in a broader sense as it happens with the open air. Thus, the variety of the cave system (number of halls, length, different levels) could count as the number of viewpoints, whereas the landscape difference could, in this case, represent the wealth of speleothems (i.e., Stalagmites, stalactites, gours, curtains, etc.).

A similar problem is encountered in the cultural criteria which are divided into four sub-criteria. A geosite may bear a high score in one sub-criterion because of its exceptional value, however it could be scored low in the rest. As a result, the final score of this criterion is low for this specific geosite even if the value of one of the sub-criteria is exceptionally high. A characteristic example is the Water of Styx geosite which has a very important mythological heritage but has low values of ethics, history and art. It thus presents a final low score on this criterion which undermines the undeniably high cultural value of this geosite. Thus, a more careful inspection and consideration in the broader sense of each of the cultural sub-criteria separately must be taken into account when implementing this methodology, or maybe the introduction of an additional one that could refer to intangible cultural heritage might also be useful.

Finally, the scoring for the number of visitors is easy to be calculated in the case that ticket offices exist (e.g., Cave of the Lakes). There, the number of visitors is recorded with accuracy. However, in geosites where the number of visitors cannot be calculated with absolute values but only approximately, the score of this criterion is questionable. Thus, an additional visitor's estimation system has to be considered under scoring.

The criteria focus on a regional level, which helps to identify the priorities of the geopark. Geosites that have high values in the touristic or educational index should be utilized in corresponding activities. Similarly, the geosites that have a high index for the need of protection are the ones that face higher risks, and it is deemed necessary to implement actions to protect them. Geosites with great touristic and educational value that are already exploited for corresponding activities, it is necessary to be maintained at this level. Conversely, in geosites with high touristic and education importance that are not exploited to date, actions such as opening of new paths or construction of funiculars etc, must be taken, so that they can be approached safely by tourists and students. Characteristic examples are the geosites Water of Styx and Psili Korfi at Chelmos Mt. According to their assessment they are geosites of great interest that certainly need enhancement. For this reason, the Management Body of Chelmos-Vouraikos, after evaluating the results of the assessment, has already planned during the following year a series of interventions for all the geosites found on Chelmos Mt (including Water of Styx and Psili Korfi) to improve accessibility to the geosites and enhance their promotion including activities in collaboration with the local Ski Center, even for people that will not be able to access the actual sites. This is a classic example of how the assessment of geosites can help the managing authorities to prioritize the needs of their geoparks. Moreover, in geosites with high protection-need, more intense protection measures need to be taken. For instance, livestock and respective facilities should be removed, as well as restrictions on crop cultivation within these geosites should be applied.

The immediate next aim of this research is to improve the existing evaluation method. Additionally, an average score for each index or criteria could be calculated for all the 
geosites of the evaluated geopark. If such a methodology is implemented by different geoparks, a comparison between them would be possible. This comparison would be helpful for the further development of all geoparks, which have as their main objective the conservation of the geological heritage and the promotion of sustainable development. In addition, by using a single rating system by different geoparks, it would be possible to propose response measures for low-scored geosites. Utilization of the above measures would be helpful for other geoparks as well facing similar difficulties.

\section{Conclusions}

In conclusion, the quantitative assessment of geosites in Chelmos-Vouraikos UGGp revealed the abundant possibilities for educational, scientific and touristic activities that the geosites can offer, such as the understanding of the Corinth rift and the thrusting of the Pindos nappe, the observation of one of the oldest formations of the Peloponnese, the creation of an impressive lake due to a catastrophic landslide as well as many other geological processes. Apart from the geological processes, the flora and fauna as well as the cultural features of the study area are rich. However, due mainly to the extensive livestock breeding in the geopark area, many geosites are endangered with degradation, both in their aesthetics and in their characteristics.

Most geosites with calculated high educational value are already used for corresponding activities from the managing authorities of the geopark. Those with a very high $\mathrm{V}_{\text {edu }}$ index have great improvement potential for Chelmos-Vouraikos UGGp. Geosites with high touristic value, which so far are not fully exploited, have highlighted the necessity to enhance their touristic development with various actions. Based on the assessment results, the geopark management has already planned actions to develop accessibility and promote the geosites of Chelmos Mt, and particularly the Water of Styx and Psili Korfi that were highly rated. Similarly, geosites with high protection index values (such as the Tectonic Graben of Kalavryta), are considered as places with a great need for protection. Sometimes protection measures such as removing/reducing livestock activities and facilities around geosites are easy to be taken, whereas in other cases protection measures are difficult because of the very high human activity.

Testing the methodology of Fassoulas et al. [19] in the area of Chelmos-Vouraikos made possible the identification of some malfunctions and elaboration problems related to caves, intangible heritage and number of visitors used in the evaluation criteria. We think that these problems can be solved with further refinement and specifications in the criteria description related with the above cases.

The assessment of geosites like the one presented herein for Chelmos-Vouraikos UGGp, performed either with the methodology we have chosen or a similar one, is considered necessary for all geoparks in order to develop effective and productive geoconservation, geoeducation and geotouristic initiatives [19]. It also highlights the importance and the way of utilization of each geosite, always with respect to nature and the environment, as well as identifying those which need further protection.

Author Contributions: Conceptualization, G.I. and P.P.; methodology, C.F. and G.I.; validation, All Authors; formal analysis, All Authors; investigation, All Authors.; data curation, V.G. and E.K.; writing-original draft preparation, V.G., P.P. and G.I.; writing-review and editing, All Authors; visualization, V.G.; supervision, G.I., N.Z., C.F. and A.Z. All authors have read and agreed to the published version of the manuscript.

Funding: Vasilis Golfinopoulos as an MSc student was financially supported by the "Andreas Mentzelopoulos Scholarships for postgraduate studies at the University of Patras", 33720000.

Institutional Review Board Statement: Not applicable.

Acknowledgments: We would like to thank the personnel of Chelmos-Vouraikos UNESCO Global Geopark for all the help they provided during fieldwork and the collection of data. Also we would like to thank Socrates Tsacos and Irena Pappa for their help during the construction of the geological map of the Geopark. 
Conflicts of Interest: The authors declare no conflict of interest.

\section{References}

1. Zouros, N. Global Geoparks Network and the New UNESCO Global Geoparks Programme. Bull. Geol. Soc. Greece 2017, 50, 284. [CrossRef]

2. UNESCO. Available online: http:/ / www.unesco.org (accessed on 2 September 2021).

3. Henriques, M.H.; Brilha, J. UNESCO Global Geoparks: A Strategy towards Global Understanding and Sustainability. Episodes 2017, 40, 349-355. [CrossRef]

4. Keever, P.J.M.; Zouros, N. Geoparks: Celebrating Earth Heritage, Sustaining Local Communities. Episodes 2005, 28, 274-278. [CrossRef] [PubMed]

5. Henriques, M.H.; dos Reis, R.P.; Brilha, J.; Mota, T. Geoconservation as an Emerging Geoscience. Geoheritage 2011, 3, 117-128. [CrossRef]

6. UNESCO. Statutes of the International Geoscience and Geoparks Programme (IGGP). Available online: https://unesdoc.unesco org/ark:/48223/pf0000234539.locale=en (accessed on 28 December 2021).

7. Catana, M.M.; Brilha, J.B. The Role of UNESCO Global Geoparks in Promoting Geosciences Education for Sustainability. Geoheritage 2020, 12, 1. [CrossRef]

8. Brilha, J.; Gray, M.; Pereira, D.I.; Pereira, P. Geodiversity: An Integrative Review as a Contribution to the Sustainable Management of the Whole of Nature. Environ. Sci. Policy 2018, 86, 19-28. [CrossRef]

9. UNESCO. Top 10 Focus Areas of UNESCO Global Geoparks. Available online: https:/ / en.unesco.org/global-geoparks/focus\# focus (accessed on 28 December 2021).

10. Vlami, V.; Kokkoris, I.P.; Zogaris, S.; Cartalis, C.; Kehayias, G.; Dimopoulos, P. Cultural Landscapes and Attributes of “Culturalness" in Protected Areas: An Exploratory Assessment in Greece. Sci. Total Environ. 2017, 595, 229-243. [CrossRef]

11. Pereira, P.; Pereira, D.; Alves, M.I.C.; Pereira, P.; Pereira, D.; Cae-Tano Alves, M.I. Geomorphosite Assessment in Montesinho Natural Park. Geogr. Helv. 2007, 62, 159-168. [CrossRef]

12. Bruschi, V.M.; Cendrero, A.; Albertos, J.A.C. A Statistical Approach to the Validation and Optimisation of Geoheritage Assessment Procedures. Geoheritage 2011, 3, 131-149. [CrossRef]

13. Zouros, N. Geomorphosite Assessment and Management in Protected Areas of Greece. The Case of the Lesvos Island-Coastal Geomorphosites. Geogr. Helv. 2007, 62, 169-180. [CrossRef]

14. Zouros, N.; Valiakos, I. Geoparks Management and Assessment. Bull. Geol. Soc. Greece 2010, 43, 965. [CrossRef]

15. Vujičić, M.D.; Vasiljević, D.A.; Marković, S.B.; Hose, T.A.; Lukić, T.; Hadžić, O.; Janićević, S. Preliminary Geosite Assessment Model (GAM) and Its Application on Fruška Gora Mountain, Potential Geotourism Destination of Serbia. Acta Geogr. Slov. 2011, 51, 361-376. [CrossRef]

16. Rivas, V.; Rix, K.; Frances, E.; Cendrero, A.; Brunsden, D. GeomoNrphological Indicators for Environmental Impact Assessment: Consumable and Non-Consumable Geomorphological Resources. Geomorphology 1997, 18, 169-182. [CrossRef]

17. Reynard, E.; Fontana, G.; Kozlik, L.; Scapozza, C. A Method for Assessing "Scientific" and "Additional Values" of Geomorphosites. Geogr. Helv. 2007, 62, 148-158. [CrossRef]

18. Bruschi, V.M.; Cendrero, A.; Quaternario, I. Geosite Evaluation; Can We Measure Intangible Values? Il Quat. 2005, 18, $293-306$.

19. Fassoulas, C.; Mouriki, D.; Dimitriou-Nikolakis, P.; Iliopoulos, G. Quantitative Assessment of Geotopes as an Effective Tool for Geoheritage Management. Geoheritage 2012, 4, 177-193. [CrossRef]

20. Brilha, J. Inventory and Quantitative Assessment of Geosites and Geodiversity Sites: A Review. Geoheritage 2016, 8, 119-134. [CrossRef]

21. Gajek, G.; Zgłobicki, W.; Kołodyńska-Gawrysiak, R. Geoeducational Value of Quarries Located Within the Małopolska Vistula River Gap (E Poland). Geoheritage 2019, 11, 1335-1351. [CrossRef]

22. Li, Y.; Li, M.; Ding, Z. Study on Methodology of Assessing Synergy between Conservation and Development of Karst Protected Area in the Case of the Diehong Bridge Scenic Area of Jiuxiang Gorge Cave Geopark, Yunnan, China. Environ. Dev. Sustain. 2021, 1-20. [CrossRef]

23. Kubalíková, L. Geomorphosite Assessment for Geotourism Purposes. Czech J. Tour. 2013, 2, 80-104. [CrossRef]

24. Kubalíková, L.; Kirchner, K. Geosite and Geomorphosite Assessment as a Tool for Geoconservation and Geotourism Purposes: A Case Study from Vizovická Vrchovina Highland (Eastern Part of the Czech Republic). Geoheritage 2016, 8, 5-14. [CrossRef]

25. Migoń, P.; Pijet-Migoń, E. Viewpoint Geosites-Values, Conservation and Management Issues. Proc. Geol. Assoc. 2017, 128, 511-522. [CrossRef]

26. Artugyan, L. Geomorphosites Assessment in Karst Terrains: Anina Karst Region (Banat Mountains, Romania). Geoheritage 2017, 9, 153-162. [CrossRef]

27. Štrba, L'; Rybár, P. Revision of the "Assessment of Attractiveness (Value) of Geotouristic Objects". Acta Geoturistica 2015,6 , 30-40.

28. Aoulad-Sidi-Mhend, A.; Maaté, A.; Hlila, R.; Martín-Martín, M.; Chakiri, S.; Maaté, S. A Quantitative Approach to Geosites Assessment of the Talassemtane National Park (NW of Morocco). Estud. Geológicos 2020, 76, 123. [CrossRef]

29. Albani, R.A.; Mansur, K.L.; de Carvalho, I.S.; dos Santos, W.F.S. Quantitative Evaluation of the Geosites and Geodiversity Sites of João Dourado Municipality (Bahia-Brazil). Geoheritage 2020, 12, 1-15. [CrossRef] 
30. Zangmo, G.T.; Kagou, A.D.; Nkouathio, D.G.; Gountié, M.D.; Kamgang, P. The Volcanic Geoheritage of the Mount Bamenda Calderas (Cameroon Line): Assessment for Geotouristic and Geoeducational Purposes. Geoheritage 2017, 9, 255-278. [CrossRef]

31. Pralong, J.-P. A Method for Assessing Tourist Potential and Use of Geomorphological Sites. Géomorphologie Relief Processus Environ. 2005, 11, 189-196. [CrossRef]

32. Dercourt, J. Contribution a l'Étude Géologique d'Un Secteur Du Péloponnèse Septentrional; University of Paris: Paris, France, 1964.

33. Koukouvelas, I. Geology of Greece; Liberal Books: Athens, Greece, 2018; ISBN 9786185012403.

34. Degnan, P.J.; Robertsoj, A.H. Mesozoic-Early Tertiary Passive Margin Evolution of the Pindos Ocean (NW Peloponnese, Greece); Elsevier: Amsterdam, The Netherlands, 1998; Volume 117, pp. 33-70.

35. Dornsiepen, U.; Gerolymatos, E.; Jacobschagen, V. Die Phyllit-Quartzit-Serie Im Fenster von Feneos (Nord-Peloponnes). IGME Geol. Geophys. Res. Spec. Issue 1986, 99-105.

36. Jolivet, L.; Labrousse, L.; Agard, P.; Lacombe, O.; Bailly, V.; Lecomte, E.; Mouthereau, F.; Mehl, C. Rifting and Shallow-Dipping Detachments, Clues from the Corinth Rift and the Aegean. Tectonophysics 2010, 483, 287-304. [CrossRef]

37. Kydonakis, K.; Kostopoulos, D.; Poujol, M.; Brun, J.P.; Papanikolaou, D.; Paquette, J.L. The Dispersal of the Gondwana Super-Fan System in the Eastern Mediterranean: New Insights from Detrital Zircon Geochronology. Gondwana Res. 2014, 25, $1230-1241$. [CrossRef]

38. Ford, M.; Hemelsdaël, R.; Mancini, M.; Palyvos, N. Rift Migration and Lateral Propagation: Evolution of Normal Faults and Sediment-Routing Systems of the Western Corinth Rift (Greece). In Geological Society Special Publication; Geological Society of London: Londok, UK, 2017; Volume 439, pp. 131-168.

39. Ford, M.; Rohais, S.; Williams, E.A.; Bourlange, S.; Jousselin, D.; Backert, N.; Malartre, F. Tectono-Sedimentary Evolution of the Western Corinth Rift (Central Greece). Basin Res. 2013, 25, 3-25. [CrossRef]

40. Moretti, I.; Sakellariou, D.; Lykousis, V.; Micarelli, L. The Gulf of Corinth: An Active Half Graben? J. Geodyn. 2003, 36, 323-340. [CrossRef]

41. Ford, M.; Williams, E.A.; Malartre, F.; Popescu, S.-M. Stratigraphic Architecture, Sedimentology and Structure of the Vouraikos Gilbert-Type Fan Delta, Gulf of Corinth, Greece. In Sedimentary Processes, Environments and Basins; Blackwell Publishing Ltd.: Oxford, UK, 2007.

42. Pope, R.J.; Hughes, P.D.; Skourtsos, E. Glacial History of Mt Chelmos, Peloponnesus, Greece. In Geological Society Special Publication; Geological Society of London: London, UK, 2017; Volume 433, pp. 211-236.

43. Tsakiri, M.; Koumoutsou, E.; Kokkoris, I.P.; Trigas, P.; Iliadou, E.; Tzanoudakis, D.; Dimopoulos, P.; Iatrou, G. National Park and UNESCO Global Geopark of Chelmos-Vouraikos (Greece): Floristic Diversity, Ecosystem Services and Management Implications. Land 2021, 11, 33. [CrossRef]

44. Dimopoulos, P.; Georgiadis, T. Floristic and Phytogeographical Analysis of Mount Killini (NE Peloponnisos). Phyton Ann. Rei Bot. 1992, 32, 282-305.

45. Trigas, P.; Tsiftsis, S.; Tsiripidis, I.; Iatrou, G. Distribution Patterns and Conservation Perspectives of the Endemic Flora of Peloponnese (Greece). Folia Geobot. 2012, 47, 421-439. [CrossRef]

46. Kokkoris, I.; Dimitrellos, G.; Kougioumoutzis, K.; Laliotis, I.; Georgiadis, T.; Tiniakou, A. The Native Flora of Mountain Panachaikon (Peloponnese, Greece): New Records and Diversity. J. Biol. Res. Thessalon. 2014, 21, 9. [CrossRef] [PubMed]

47. Mikhailenko, A.V.; Ruban, D.A.; Ermolaev, V.A. Accessibility of Geoheritage Sites-A Methodological Proposal. Heritage 2021, 4, 1080-1091. [CrossRef]

48. Mikhailenko, A.V.; Nazarenko, O.V.; Ruban, D.A.; Zayats, P.P. Aesthetics-Based Classification of Geological Structures in Outcrops for Geotourism Purposes: A Tentative Proposal. Geologos 2017, 23, 45-52. [CrossRef]

49. Štrba, L.; Kršák, B.; Sidor, C. Some Comments to Geosite Assessment, Visitors, and Geotourism Sustainability. Sustainability 2018, 10, 2589. [CrossRef]

50. Reynard, E.; Perret, A.; Bussard, J.; Grangier, L.; Martin, S. Integrated Approach for the Inventory and Management of Geomorphological Heritage at the Regional Scale. Geoheritage 2016, 8, 43-60. [CrossRef]

51. Kokkoris, I.P.; Drakou, E.G.; Maes, J.; Dimopoulos, P. Ecosystem Services Supply in Protected Mountains of Greece: Setting the Baseline for Conservation Management. Int. J. Biodivers. Sci. Ecosyst. Serv. Manag. 2018, 14, 45-59. [CrossRef]

52. Cheminal, A.; Kokkoris, I.P.; Strid, A.; Dimopoulos, P. Medicinal and Aromatic Lamiaceae Plants in Greece: Linking Diversity and Distribution Patterns with Ecosystem Services. Forests 2020, 11, 661. [CrossRef]

53. Tan, K.; Iatrou, G. Endemic Plants of Greece. The Peloponnese; Gads Forlag: Copenhagen, Denmark, 2001; ISBN 9788712038573.

54. Trikolas, K. Geological Study of The Wider Area of Aegialia And Kalavryta. Ph.D. Thesis, National Technical University of Athens Faculty of Mining Engineering and Metallurgy Section of Geological Sciences, Athens, Greece, 2008. (In Greek). [CrossRef]

55. Trikolas, C.; Alexouli-Livaditi, A. Geological Structure of the Wider Area of Aegialia and Kalavryta (North Peloponnesus). Bull. Geol. Soc. Greece 2004, 36, 1568. [CrossRef]

56. Jones, W.H.S.; Wycherley, E.; Orrod, H.H. Pausanias Description of Greece: With an English Translation; Harvard University Press: Cambrigde, MA, USA, 1969.

57. Frazer, J.G. Apollodorus, The Library, with an English Translation; Harvard University Press: Cambridge, MA, USA, 1963.

58. Pollio, M.V.; Gwilt, J. The Architecture of Vitruvius, Book VIII. In The Architecture of Marcus Vitruvius Pollio; Cambridge University Press: Cambridge, MA, USA, 2015; pp. 227-258.

59. Cave of Lakes. Available online: https://www.kastriacave.gr (accessed on 2 September 2021). 
60. Koutsi, R. The Role of Epikarst in the Estimation and Mapping of Karstic Aquifers' Vulnerability, Using the Newly Developed European Method. Ph.D. Thesis, Department of Geology, National and Kapodistrian University of Athens, Athens, Greece, 2007. (In Greek). [CrossRef]

61. Ocasio-Morales, R.G.; Tsopelas, P.; Harrington, T.C. Origin of Ceratocystis Platani on Native Platanus Orientalis in Greece and Its Impact on Natural Forests. Plant Disease 2007, 91, 901-904. [CrossRef] [PubMed]

62. Tsopelas, P.; Angelopoulos, A. First Report of Canker Stain Disease of Plane Trees, Caused by Ceratocystis fimbriata f. Sp. Platani in Greece. Plant Pathol. 2004, 53, 531. [CrossRef]

63. Zygouri, V.; Koukouvelas, I.K. Landslides and Natural Dams in the Krathis River, North Peloponnese, Greece. Bull. Eng. Geol. Environ. 2019, 78, 207-222. [CrossRef]

64. Greek Travel Pages. Available online: https://www.gtp.gr (accessed on 2 September 2021).

65. Sharples, C. Concepts and Principles of Geoconservation; Tasmanian Parks \& Wildlife Service: St Helens, Australia, 2002.

66. Prosser, C.D.; Brown, E.J.; Larwood, J.G.; Bridgland, D.R. Geoconservation for Science and Society-An Agenda for the Future. Proc. Geol. Assoc. 2013, 124, 561-567. [CrossRef]

67. Gray, M. Geodiversity: Valuing and Conserving Abiotic Nature, 2nd ed.; John Wiley \& Sons: Chichester, UK, 2013.

68. Gordon, E.J.; Crofts, R.; Díaz-Martínez, E. Geoheritage Conservation and Environmental Policies. In Geoheritage; Elsevier: Amsterdam, The Netherlands, 2018; pp. 213-235.

69. Prosser, C.D.; Díaz-Martínez, E.; Larwood, J.G. The Conservation of Geosites. In Geoheritage; Elsevier: Amsterdam, The Netherlands, 2018; pp. 193-212.

70. Crofts, R.; Gordon, J.E.; Brilha, J.; Gray, M.; Gunn, J.; Larwood, J.; Santucci, V.; Tormey, D.; Worboys, G.L. Guidelines for Geoconservation in Protected and Conserved Areas; Groves, C., Ed.; International Union for Conservation of Nature: Gland, Switzerland, 2020; ISBN 9782831720791.

71. Gordon, J.E. Geoconservation Principles and Protected Area Management. Int. J. Geoheritage Parks 2019, 7, 199-210. [CrossRef]

72. Farsani, N.T.; Coelho, C.O.A.; Costa, C.M.M.; Amrikazemi, A. Geo-Knowledge Management and Geoconservation via Geoparks and Geotourism. Geoheritage 2014, 6, 185-192. [CrossRef] 